\section{Pacific Northwest}

National Laboratory

Operated by Battelle for the

U.S. Department of Energy

\title{
Mixed Alcohol Synthesis \\ Catalyst Screening 2007 Progress Report
}

\author{
M. A. Gerber \\ J. F. White \\ M. J. Gray \\ D. J. Stevens
}

November 2007

\author{
Prepared for the U.S. Department of Energy \\ under Contract DE-AC05-76RL01830
}




\title{
DISCLAIMER
}

This report was prepared as an account of work sponsored by an agency of the United States Government. Neither the United States Government nor any agency thereof, nor Battelle Memorial Institute, nor any of their employees, makes any warranty, express or implied, or assumes any legal liability or responsibility for the accuracy, completeness, or usefulness of any information, apparatus, product, or process disclosed, or represents that its use would not infringe privately owned rights. Reference herein to any specific commercial product, process, or service by trade name, trademark, manufacturer, or otherwise does not necessarily constitute or imply its endorsement, recommendation, or favoring by the United States Government or any agency thereof, or Battelle Memorial Institute. The views and opinions of authors expressed herein do not necessarily state or reflect those of the United States Government or any agency thereof.

\author{
PACIFIC NORTHWEST NATIONAL LABORATORY \\ operated by \\ BATTELLE \\ for the \\ UNITED STATES DEPARTMENT OF ENERGY \\ under Contract DE-AC05-76RL01830 \\ Printed in the United States of America \\ Available to DOE and DOE contractors from the \\ Office of Scientific and Technical Information, \\ P.O. Box 62, Oak Ridge, TN 37831-0062; \\ ph: (865) 576-8401 \\ fax: (865) 576-5728 \\ email: reports@adonis.osti.gov
}

Available to the public from the National Technical Information Service, U.S. Department of Commerce, 5285 Port Royal Rd., Springfield, VA 22161

ph: (800) 553-6847

fax: (703) 605-6900

email: orders@ntis.fedworld.gov

online ordering: http://www.ntis.gov/ordering.htm 


\title{
Mixed Alcohol Synthesis \\ Catalyst Screening 2007 Progress Report
}

\author{
M. A. Gerber \\ J. F. White \\ M. J. Gray \\ D. J. Stevens
}

November 2007

Prepared for

the U.S. Department of Energy

under Contract DE-AC05-76RL01830

Pacific Northwest National Laboratory

Richland, Washington 


\section{Summary}

The U.S. Department of Energy's (DOE) Pacific Northwest National Laboratory (PNNL) and National Renewable Energy Laboratory (NREL) are conducting research to investigate the feasibility of producing mixed alcohols from biomass-derived synthesis gas (syngas). PNNL is tasked with obtaining commercially available mixed alcohol or preparing promising mixed-alcohol catalysts and screening them in a laboratory-scale reactor system. Commercially available catalysts and the most promising experimental catalysts are provided to NREL for testing using a slipstream from a pilot-scale biomass gasifier.

After a review of the literature in 2006 and conversations with companies that produced catalysts, it was determined that no commercial mixed-alcohol synthesis catalysts were available at the time. One catalyst manufacturer did supply a modified methanol catalyst that was tested in the PNNL laboratoryscale system and was provided to NREL for further testing. PNNL also prepared and tested the behavior of 10 other catalysts representing the distinct catalyst classes for mixed alcohol syntheses. Based on those results, further testing in 2007 focused on the performance of rhodium-based catalysts. The effects of adding promoters to the rhodium catalysts in addition to the manganese already being used were examined. The test conditions and the range of $\mathrm{C}_{2}{ }^{+}$oxygenate space-time yields (STYs) for these catalysts plus the previously tested rhodium-based catalysts are shown in Table S.1.

Table S.1. Summary of Test Results

\begin{tabular}{|c|c|c|c|c|c|c|c|}
\hline Catalyst & Promoters & $\begin{array}{c}\text { Pressure } \\
\text { (atm) }\end{array}$ & $\begin{array}{c}\text { Temperature } \\
\left({ }^{\circ} \mathrm{C}\right)\end{array}$ & $\begin{array}{c}\text { GHSV } \\
\left(\mathbf{L} / \mathbf{L}_{\text {cat }} / \mathbf{h r}\right)\end{array}$ & $\begin{array}{c}\text { STY of } \mathrm{C}_{2}^{+} \\
\text {Oxygenates }^{(a)} \\
\left(\mathrm{g} / \mathrm{L}_{\text {cat }} / \mathrm{hr}\right)\end{array}$ & $\begin{array}{c}\text { Selectivity } \\
\text { to } \mathrm{C}_{2}^{+} \\
\text {Oxygenates }\end{array}$ & $\begin{array}{c}\text { Ratio of } \mathrm{C}_{2}^{+} \\
\text {Alcohols } \\
\text { to } \mathrm{C}_{2}^{+} \\
\text {Oxygenates }\end{array}$ \\
\hline $\mathrm{Rh} / \mathrm{Mn} / \mathrm{SiO}_{2}$ & $\mathrm{Mn}$ & 80 & $255-305$ & 3,300 & $110-150$ & $23-45$ & $0.26-0.51$ \\
\hline $\mathrm{Rh} / \mathrm{Mn} / \mathrm{Fe} / \mathrm{SiO}_{2}$ & $\mathrm{Mn}, \mathrm{Fe}$ & 80 & $257-402$ & $7,400-15,000$ & $170-400$ & $11-42$ & $0.32-0.75$ \\
\hline $\mathrm{Rh} / \mathrm{Mn} / \mathrm{Li} / \mathrm{SiO}_{2}$ & $\mathrm{Mn}, \mathrm{Li}$ & 80 & $256-350$ & $7,400-15,000$ & $90-480$ & $34-62$ & $0.19-0.56$ \\
\hline $\mathrm{Rh} / \mathrm{Mn} / \mathrm{Ni} / \mathrm{SiO}_{2}$ & Mn, Ni & 80 & $256-325$ & $7,400-15,000$ & $130-480$ & $21-46$ & $0.17-0.36$ \\
\hline $\mathrm{Rh} / \mathrm{Mn} / \mathrm{Ir} / \mathrm{SiO}_{2}$ & Mn, Ir & 80 & $256-328$ & $7,400-15,000$ & $290-880$ & $23-58$ & $0.10-0.37$ \\
\hline $\mathrm{Rh} / \mathrm{Mn} / \mathrm{Re} / \mathrm{SiO}_{2}$ & Mn, Re & 80 & $256-324$ & $7,400-15,000$ & $210-260$ & $16-36$ & $0.25-0.61$ \\
\hline $\mathrm{Rh} / \mathrm{Mn} / \mathrm{Cu} / \mathrm{SiO}_{2}$ & $\mathrm{Mn}, \mathrm{Cu}$ & 80 & $256-337$ & $7,400-15,000$ & $60-150$ & $21-46$ & $0.34-0.62$ \\
\hline $\mathrm{Rh} / \mathrm{Mn} / \mathrm{Co} / \mathrm{SiO}_{2}$ & Mn, Co & 80 & $256-323$ & $7,400-15,000$ & $140-350$ & $21-50$ & $0.19-0.46$ \\
\hline
\end{tabular}

Based on the promoters tested to date, the following general conclusions can be made:

- Highest $\mathrm{C}_{2}^{+}$oxygenate STYs occur between $300^{\circ}$ and $325^{\circ} \mathrm{C}$ where carbon conversion ranges between $\sim 25$ and 40\% (except for the RhMnCu catalyst, which had 9\% carbon conversion).

- Carbon selectivities to $\mathrm{C}_{2}{ }^{+}$oxygenates decrease with increasing reaction temperatures because of higher carbon conversion to hydrocarbons.

- Carbon selectivities of the organics in the aqueous phase to $\mathrm{C}_{2}{ }^{+}$alcohols increase with higher reaction temperatures than the other oxygenates present there.

- The highest carbon selectivity to $\mathrm{C}_{2}^{+}$oxygenates occurs at lower reaction temperatures and accompanying lower STYs. 
In addition to these general trends, the test results singled out specific promoters that showed potential for improving the rhodium-based catalysts. The iridium promoter stood out in terms of significantly improving the STY of oxygenates with a maximum observed STY of $\sim 880 \mathrm{~g} / \mathrm{Lcat} / \mathrm{hr}$, followed by lithium and nickel with observed maximum STYs of $480 \mathrm{~g} / \mathrm{Lcat} / \mathrm{hr}$. Selectivities to $\mathrm{C}_{2}{ }^{+}$ oxygenates at the maximum $\mathrm{C}_{2}{ }^{+}$oxygenate STYs were 39,47 , and $32 \%$, respectively, under these conditions. Rhenium and copper promoters were relatively unremarkable in terms of STYs.

The iron and rhenium promoters both stood out as achieving higher carbon selectivities to $\mathrm{C}_{2}^{+}$ alcohols with respect to all oxygenates in the aqueous product, followed by copper, with carbon selectivity ratios of $0.64,0.60$, and 0.47 , respectively, at conditions in which each achieved its highest $\mathrm{C}_{2}{ }^{+}$ oxygenate STY. Iridium and $\mathrm{Li}$, on the other hand, had low carbon selectivity ratios of 0.27 and 0.22 , respectively.

Although testing of candidate promoters is not complete, it appears that Ir and Li promoters will warrant further optimization and possibly combination to further improve STYs and carbon selectivities to $\mathrm{C}_{2}{ }^{+}$oxygenates. However, by using these promoters, it will be necessary to incorporate a separate hydrogenation catalyst to improve the yield of $\mathrm{C}_{2}{ }^{+}$alcohols with respect to the other oxygenates. Fe, Re, and $\mathrm{Cu}$ stand out as possible candidates in this respect, but additional research is needed to examine whether they can be combined with the other promoters on the $\mathrm{Rh} / \mathrm{Mn} / \mathrm{SiO}_{2}$ catalyst or need to be optimized on a separate catalyst support that is either physically mixed or used in series with the promoted $\mathrm{Rh} / \mathrm{Mn} / \mathrm{SiO}_{2}$-based catalyst. 


\section{Contents}

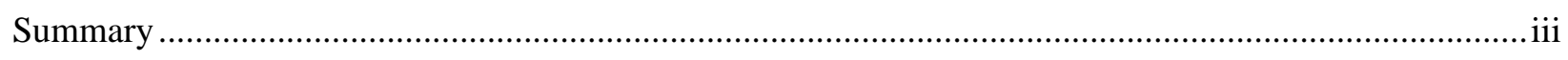

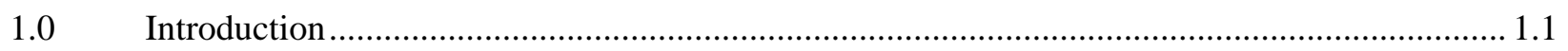

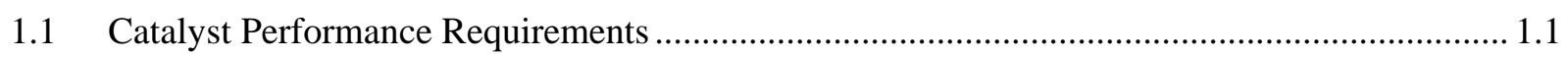

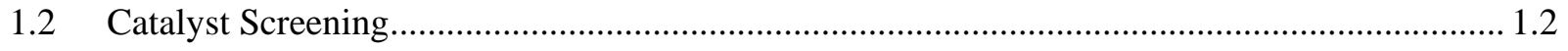

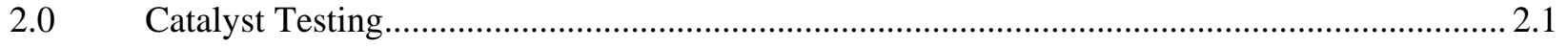

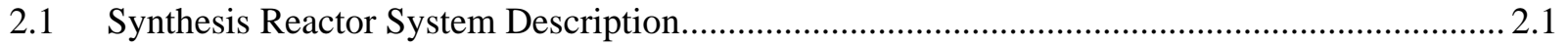

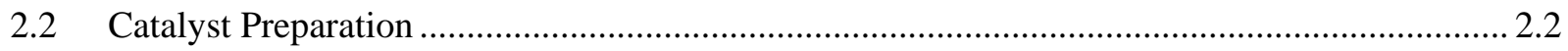

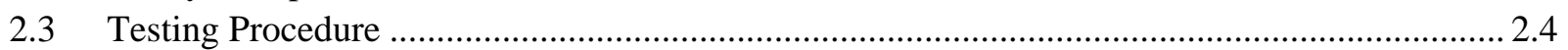

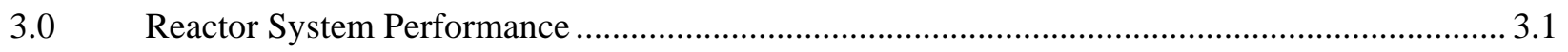

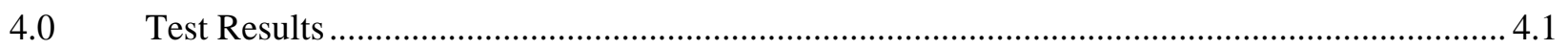

4.1 Examination of Catalyst Preparation Techniques .................................................................... 4.1

4.2 Examination of the Catalyst Reduction Temperature .............................................................. 4.1

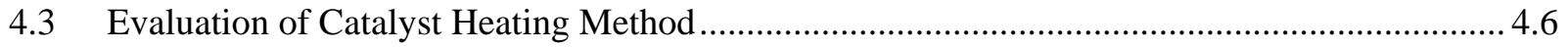

4.4 Comparison of the Effects of Promoters on Catalyst Performance........................................... 4.6

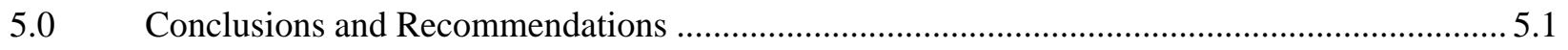

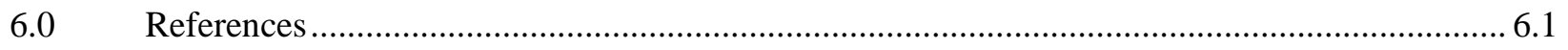

Appendix - Catalyst Testing Data ................................................................................................ A.1 


\section{Figures}

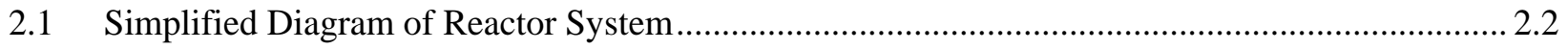

$4.1 \mathrm{C}_{2}{ }^{+}$Oxygenate STYs for Iron-Promoted Catalysts.................................................................. 4.2

4.2 Carbon Selectivities to $\mathrm{C}_{2}{ }^{+}$Oxygenates for Iron-Promoted Catalysts ............................................ 4.2

4.3 Carbon Conversion of Li-Promoted Catalysts......................................................................... 4.4

$4.4 \mathrm{C}_{2}{ }^{+}$Oxygenate STYs for Li-Promoted Catalysts......................................................................... 4.4

4.5 Carbon Selectivity to $\mathrm{C}_{2}{ }^{+}$Oxygenates for Li-Promoted Catalysts ............................................... 4.5

4.6 Carbon Selectivity of All Oxygenates to $\mathrm{C}_{2}{ }^{+}$Alcohols for Li-Promoted Catalysts.......................... 4.5

4.7 Comparison of Hydrocarbon Selectivities for Li-Promoted Catalysts ........................................... 4.6

4.8 Comparison of $\mathrm{C}_{2}{ }^{+}$Alcohols and $\mathrm{C}_{2}{ }^{+}$Oxygenate STYs for $\mathrm{RhMn} / \mathrm{SiO}_{2}$ Catalysts with Different Promoters at Conditions Producing Maximum $\mathrm{C}_{2}{ }^{+}$Oxygenate STYs........................... 4.8

4.9 Comparison of Carbon Selectivities for $\mathrm{RhMn} / \mathrm{SiO}_{2}$ Catalysts with Different Promoters at Conditions Producing Maximum $\mathrm{C}_{2}{ }^{+}$Oxygenate STYs.

4.10 Comparison of $\mathrm{C}_{2}^{+}$Alcohols and Oxygenate STYs for $\mathrm{RhMn} / \mathrm{SiO}_{2}$ Catalysts with Different Promoters at Conditions Producing Maximum Carbon Selectivities to $\mathrm{C}_{2}{ }^{+}$Oxygenates.....

4.11 Comparison of Carbon Selectivities for $\mathrm{RhMn} / \mathrm{SiO}_{2}$ Catalysts with Different Promoters at Conditions Producing Maximum Carbon Selectivities to $\mathrm{C}_{2}{ }^{+}$Oxygenates

4.12 Carbon Selectivities to $\mathrm{C}_{2}{ }^{+}$Alcohols with Respect to all Oxygenates for $\mathrm{RhMn} / \mathrm{SiO}_{2}$ Catalysts with Different Promoters at Conditions Producing Maximum $\mathrm{C}_{2}^{+}$Oxygenate STYs

4.13 Carbon Selectivities to $\mathrm{C}_{2}{ }^{+}$Alcohols with Respect to All Oxygenates for $\mathrm{RhMn} / \mathrm{SiO}_{2}$ Catalysts with Different Promoters at Conditions Producing Maximum Carbon Selectivities to $\mathrm{C}_{2}^{+}$Oxygenates 


\section{Tables}

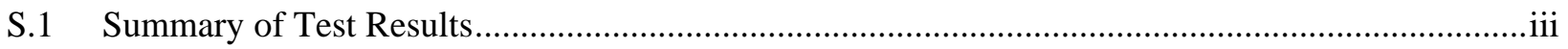

2.1 Nominal and Actual Composition of Syngas Used in Tests..........................................................2.3

2.2 List of Catalysts Tested and Corresponding Labels .................................................................... 2.3

4.1 Summary of Test Results at Conditions for Maximum $\mathrm{C}_{2}{ }^{+}$Oxygenate STYs

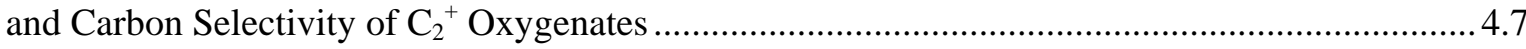

4.2 Carbon Selectivity Breakdown of Oxygenates for $\mathrm{RhMn} / \mathrm{SiO}_{2}$ Catalysts with Different Promoters at Conditions Producing Maximum $\mathrm{C}_{2}{ }^{+}$Oxygenate STYs.......................................... 4.11

4.3 Carbon Selectivity Breakdown of Oxygenates for $\mathrm{RhMn} / \mathrm{SiO}_{2}$ Catalysts with Different Promoters at Conditions Producing Maximum Carbon Selectivities to $\mathrm{C}_{2}^{+}$Oxygenates 


\subsection{Introduction}

The U.S. Department of Energy's (DOE) National Renewable Energy Laboratory (NREL) conducted technical and economic assessments of the feasibility of producing mixed alcohols as a primary product from biomass-derived synthesis gas (syngas) to complement alcohol fuel biosynthesis in an integrated biorefinery (Phillips et al. 2007). The gasification process was based on a low-pressure, indirectly heated, entrained-flow gasifier developed by Battelle. Downstream gas conditioning steps such as tar and light hydrocarbon reforming, sulfur removal, and gas compression were included to produce a syngas suitable for mixed alcohol fuel synthesis. After a review of the literature, the mixed alcohol synthesis process was based on the expected performance of a cobalt/molybdenum sulfide catalyst using methanol recycle in the synthesis reactor. The process increased the yield of higher alcohols and potentially recovered and recycled carbon dioxide from the product gas stream to a steam reformer to facilitate obtaining the desired syngas composition. Ethanol and higher alcohols were identified as the major products. Methane, light hydrocarbons, unreacted $\mathrm{CO}$, and $\mathrm{H}_{2}$ were recycled to the synthesis reactor to maximize $\mathrm{CO}$ conversion. A purge stream taken from the recycled gas loop prevented excessive buildup of certain compounds.

\subsection{Catalyst Performance Requirements}

An integral part of the techno-economic assessment of this process was the assumption regarding the mixed-alcohol fuel-synthesis catalyst. The performance of the catalyst affects the capital costs of the synthesis process in terms of reactor vessel size for a given throughput and gas recycle requirements, as well as vessel wall materials and thickness to meet design requirements for the expected operating pressure and temperature. Catalyst performance also affects the operating costs of the process in terms of energy required to pressurize and heat the incoming gas feed and the yield and distribution of key products (higher alcohols) and potential byproducts with significant economic value.

The mixed alcohol synthesis catalyst forming the basis of the evaluation was based on a class of catalysts consisting of alkali-doped molybdenum sulfide with other metals such as cobalt added to promote the selective production of mixed alcohols. One purported advantage of this class of catalyst is its tolerance for sulfur in the syngas. Operating conditions and catalyst performance were based in part on the catalysts developed and tested by Quarderer (1986) and Quarderer and Cochran (1986), and patented by Dow Chemical Company and in part on typical values reported in the literature for similar catalysts in this class.

After review of the literature and conversations with selected catalyst manufacturers, it was determined that no molybdenum-based catalysts were commercially available. In fact, the only mixed alcohol synthesis catalyst offered by a catalyst manufacturer at the time of our initial investigation was a modified methanol catalyst. The only other company found to have previously offered a commercial catalyst was Institut Francais du Petrole (IFP), who developed catalysts based on $\mathrm{Cu} / \mathrm{Co}$ and $\mathrm{Cu} / \mathrm{Ni}$ systems. Their work has been discontinued, and there is no longer any catalyst available for testing.

While testing was conducted using the modified methanol catalyst, a review of prior research was also performed to identify other potential catalysts, including molybdenum-based catalysts that showed promise for mixed alcohol synthesis. The primary screening and selection criterion for catalyst performance was the space-time yield (STY) of $\mathrm{C}_{2}{ }^{+}$oxygenated hydrocarbons, with consideration given 
to the coproduction of methanol and liquid hydrocarbons. While the NREL techno-economic study cited an STY of 250 to $350 \mathrm{~g}$ mixed alcohol $/ \mathrm{L}_{\text {cat }} / \mathrm{hr}$ as a productivity rate typical of the molybdenum catalysts, this value was considered marginal based on the assessment made by Stiles et al. (1991), who stated that methanol synthesis plants ranged from approximately 670 to $1,340 \mathrm{~g}_{\mathrm{MeOH}} / \mathrm{L}_{\mathrm{cat}} / \mathrm{hr}$. According to Stiles et al., higher methanol production rates create heat dissipation requirements that are difficult to manage. Production rates involving higher alcohol production create higher exothermic heat loads than a comparable production rate of methanol. Furthermore, when significant methane or methane and higher hydrocarbons are produced along with the alcohols, heat dissipation can become unmanageable at the higher production rates. Consequently, it may not be practical to obtain higher alcohol production rates at the upper end of the range for methanol production in conventional fixed-bed reactor systems. On the other hand, rates significantly lower than the lower production range for methanol will likely result in unacceptable process economics.

\subsection{Catalyst Screening}

In the absence of commercial catalysts having higher alcohol production rates at levels needed to achieve economic viability, this project was undertaken to identify the most promising catalysts and test them in a bench-scale system to determine which ones had the best performance. Potential catalysts were divided into five general classes:

- modified methanol catalysts (Cu/Zn and $\mathrm{Cu} / \mathrm{Mn}$ based)

- modified molybdenum sulfide catalysts

- modified molybdenum oxide catalysts

- rhodium-based catalysts

- modified Fischer-Tropsch catalysts.

The initial approach taken in this study was to obtain or prepare catalysts that were either representative of each class of catalysts or that had the potential to achieve high STYs for $\mathrm{C}_{2}^{+}$oxygenates and test them under conditions that would optimize $\mathrm{C}_{2}{ }^{+}$STYs at a common operating pressure (80 atm). Ten catalysts representative of the different catalyst classes were prepared and tested in 2006 and early 2007 along with the modified methanol catalyst provided by a catalyst manufacturer (Gerber et al. 2007). Of these catalysts, only the modified Fischer-Tropsch and rhodium-based catalysts showed promise for achieving the necessary STYs.

The two Fischer-Tropsch catalysts, modified to improve oxygenate yields achieved $\mathrm{C}_{2}^{+}$oxygenate STYs that were within the recommended range. However, because of their much higher selectivity to Fischer-Tropsch liquids, the STYs for total organic liquids exceeded the recommended range under optimum operating conditions. One of the catalysts under test conditions that produced a total organic liquid within the recommended range $\left(1200 \mathrm{~g} / \mathrm{L}_{\text {cat }} / \mathrm{hr}\right.$ total organic liquids STY)achieved a much lower $\mathrm{C}_{2}{ }^{+}$ oxygenate STY $\left(230 \mathrm{~g} / \mathrm{L}_{\text {cat }} / \mathrm{hr}\right)$, which, while higher than that achieved modified methanol and modified molybdenum catalysts, was still well below the recommended STY range with a maximum. Carbon selectivity to $\mathrm{C}_{2}^{+}$oxygenates was only about $10 \%$ under these conditions. 
The two rhodium-based catalysts, $\mathrm{Rh} / \mathrm{Mn} / \mathrm{SiO}_{2}$ and $\mathrm{Rh} / \mathrm{Mn} / \mathrm{Fe} / \mathrm{SiO}_{2}$, were very selective to $\mathrm{C}_{2}{ }^{+}$ oxygenates. The $\mathrm{Rh} / \mathrm{Mn} / \mathrm{Fe} / \mathrm{SiO}_{2}$ achieved higher $\mathrm{C}_{2}{ }^{+}$oxygenate STYs under optimum conditions than any of the modified methanol and molybdenum-based catalysts tested at their optimum conditions and the Fischer-Tropsch catalysts at conditions that limited the total organic STYs to within the recommended range. The maximum achieved $\mathrm{C}_{2}{ }^{+}$oxygenate STY ( 400 g/L $\left.\mathrm{L}_{\text {cat }} / \mathrm{hr}\right)$, however, was still below the recommended minimum. The carbon selectivity to $\mathrm{C}_{2}{ }^{+}$oxygenates under this condition was $\sim 24 \%$, which was significantly better than the Fischer-Tropsch catalysts. This rhodium catalyst was also unique because it produced very little $\mathrm{C}_{1}$ oxygenates or Fischer-Tropsch liquids. Base on these results, the next stage of catalyst testing in 2007 focused on the rhodium-based catalyst to examine the effects of other promoters besides Fe on catalyst performance. 


\subsection{Catalyst Testing}

The first set of tests to screen different classes of mixed alcohols synthesis catalysts was completed in FY 2007 and described in Gerber et al. (2007). The second set of catalyst tests at Pacific Northwest National Laboratory (PNNL) was started in 2007 and evaluated six rhodium-based catalysts in addition to the two that were tested in previous catalyst screening. The synthesis reactor system and the catalysts tested are described in this section.

\subsection{Synthesis Reactor System Description}

A bench-scale tubular reactor system was designed to operate at pressures up to 1200 psig and temperatures up to $450^{\circ} \mathrm{C}$. The catalyst chamber was $1.67 \mathrm{~cm}$ long and $1 / 4 \mathrm{in}$. in diameter. A 1/16-in. $(0.159-\mathrm{cm})$ outer-diameter thermocouple sheath extended through the center of the reactor, creating an annulus-shaped catalyst chamber. Two thermocouples inside the sheath were spaced so that one was at the center of the catalyst bed and the other just upstream.

Figure 2.1 is a simplified diagram of the reactor system. During a portion of the testing the reactor was placed in a furnace. In later tests the furnace was replaced by a hot oil circulating system to heat the reactor. Heating the reactor with hot oil provided better temperature control because it could remove the heat of reaction more efficiently, preventing thermal excursions when the carbon conversion was too high.

Syngas was metered through a mass flow controller. The system also metered reducing gas (10\% hydrogen in nitrogen) and nitrogen to the reactor during catalyst reduction. The raw product gas leaving the reactor was passed through a cold trap to condense liquids at $0^{\circ} \mathrm{C}$ and through a back-pressure regulator that controlled the system pressure. A separate bypass line containing a cold trap was used during startup and initial aging of the catalyst.

The nominal feed rate to the reactor was determined by calibrating the mass flow controllers at system pressure before the tests using a bubble flow meter downstream of the back-pressure flow regulator. Bubble flow-meter readings were corrected for standard pressure, temperature, and moisture content introduced by the bubble flow meter. The bubble flow meter downstream of the back-pressure regulator was also used to monitor product gas flow rate downstream of the liquid sample traps during each test.

Product gas grab samples were obtained downstream of the back-pressure regulator in a line separate from that containing the bubble flow meter, as shown in Figure 2.1. The reactor inlet, catalyst bed, cold sample trap, ambient temperature, and upstream gas and ambient pressures were monitored during tests.

Gas cylinders containing a specified syngas mixture were used in the tests. The gas mixture consisted of hydrogen $\left(\mathrm{H}_{2}\right)$, carbon monoxide $(\mathrm{CO})$, carbon dioxide $\left(\mathrm{CO}_{2}\right)$ and nitrogen $\left(\mathrm{N}_{2}\right)$. Most of the tests conducted with the rhodium-based catalysts used a gas that had a nominal $\mathrm{H}_{2} / \mathrm{CO}$ ratio of 1.8 that ranged from 1.7 to 1.9. Some of the earlier tests using $\mathrm{RhMnFe}$ and $\mathrm{RhMn}$ compositions had $\mathrm{H}_{2}$ : $\mathrm{CO}$ ratios that 


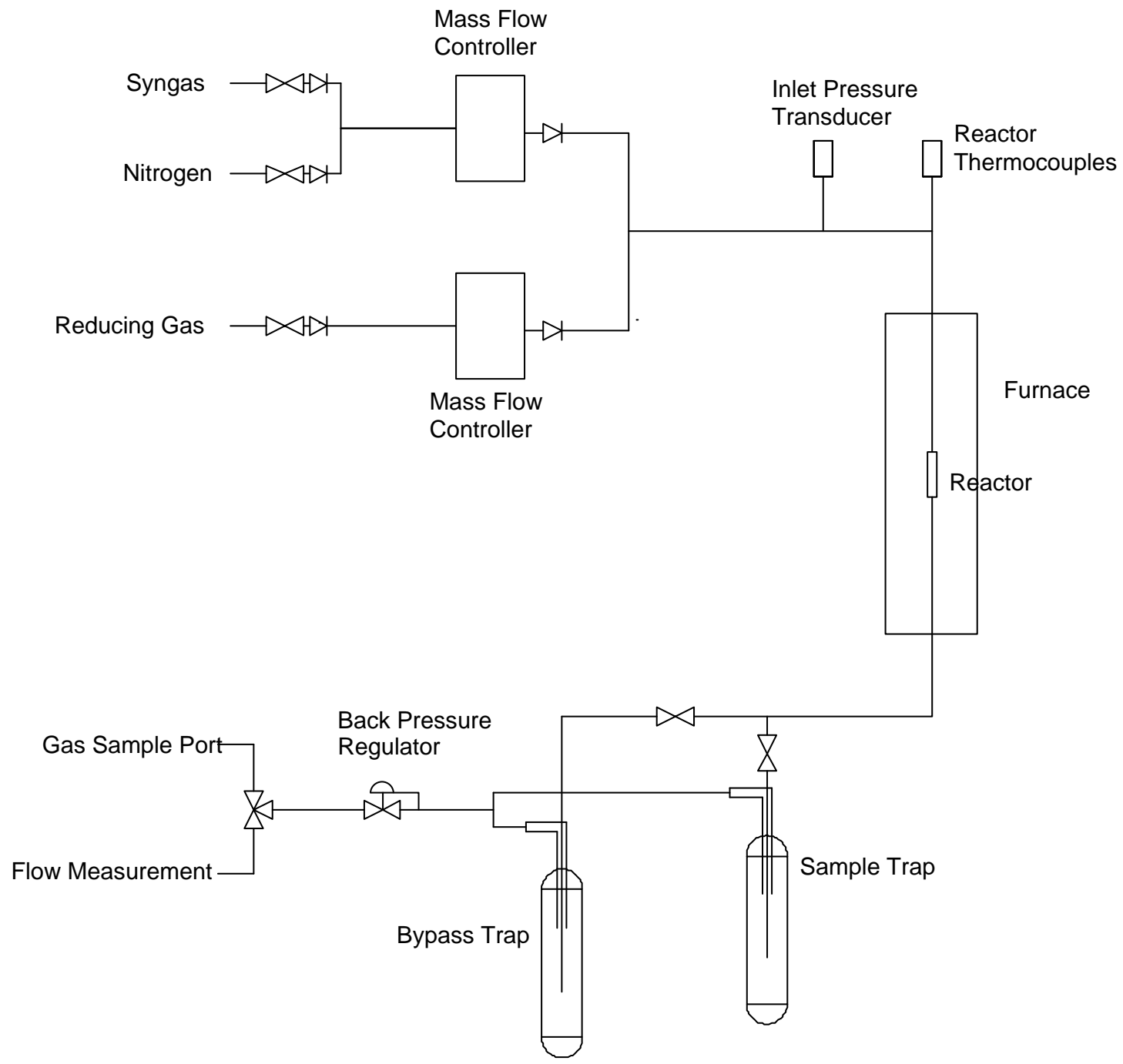

Figure 2.1. Simplified Diagram of Reactor System

ranged from 2.0 to 2.4. The nominal composition of the gas is shown in Table 2.1. Also shown are the measured concentrations of the feed gas used in the tests. The variation in the component concentrations in the feed gas are attributed to variations in the composition of the individual gas cylinder mixtures that were supplied for the tests.

\subsection{Catalyst Preparation}

The 12 catalysts tested at PNNL are shown in Table 2.2, along with the labels used in this report. 
Table 2.1. Nominal and Actual Composition of Syngas Used in Tests

\begin{tabular}{|c|c|c|c|}
\hline & Gas & $\begin{array}{c}\text { Nominal } \\
\text { Concentration } \\
(\%)\end{array}$ & $\begin{array}{c}\text { Measured } \\
\text { Concentration } \\
(\%)\end{array}$ \\
\hline \multirow{4}{*}{$\begin{array}{l}\text { High } \mathrm{H}_{2}: \text { CO Ratio Feed Gas } \\
\text { (RhMn/SiO } \\
\text { RhMnFe/ } \\
\text { RhMnFe } / \mathrm{SiO}_{2} \mathrm{~A}, \\
\text { RhMnFe/ } / \mathrm{SiO}_{2} \text { B and catalysts) }\end{array}$} & $\mathrm{H}_{2}$ & 63 & $66.2-62.0$ \\
\hline & $\mathrm{CO}$ & 29 & $26.0-32.4$ \\
\hline & $\overline{\mathrm{CO}_{2}}$ & 4 & $2.4-5.6$ \\
\hline & $\mathrm{N}_{2}$ & 4 & $2.9-5.5$ \\
\hline \multirow{4}{*}{$\begin{array}{l}\text { Low } \mathrm{H}_{2}: \text { CO ratio Feed Gas } \\
\text { (all catalysts except } \\
\text { RhMn } / \mathrm{SiO}_{2} \mathrm{~A} \text { catalyst) }\end{array}$} & $\mathrm{H}_{2}$ & 60 & $61.2-57.7$ \\
\hline & $\mathrm{CO}$ & 32 & $31.0-33.9$ \\
\hline & $\mathrm{CO}_{2}$ & 4 & $3.6-4.5$ \\
\hline & $\mathrm{N}_{2}$ & 4 & $3.6-4.5$ \\
\hline
\end{tabular}

Table 2.2. List of Catalysts Tested and Corresponding Labels

\begin{tabular}{|l|l|c|l||}
\hline \multicolumn{1}{|c|}{ Label } & \multicolumn{1}{|c|}{ Support } & $\begin{array}{c}\text { Rh } \\
\text { Concentration, } \\
\text { \% }\end{array}$ & $\begin{array}{l}\text { Rh:Mn:M } \\
\text { Ratio }\end{array}$ \\
\hline $\mathrm{RhMn} / \mathrm{SiO}_{2} \mathrm{~A}^{\mathrm{a}}$ & Davisil 645 & 5.57 & $1.00: 0.57: 0.10$ \\
\hline $\mathrm{RhMnFe} / \mathrm{SiO}_{2} \mathrm{~A}^{\mathrm{a}}$ & Davisil 645 & 5.57 & $1.00: 0.57: 0.10$ \\
\hline $\mathrm{RhMnFe} / \mathrm{SiO}_{2}$ & Davisil 645 & 5.57 & $1.00: 0.57: 0.10$ \\
\hline $\mathrm{RhMnFe} / \mathrm{SiO}_{2} \mathrm{~B}$ & Davisil LC150 & 5.57 & $1.00: 0.57: 0.10$ \\
\hline $\mathrm{RhMnLi} / \mathrm{SiO}_{2}$ & Davisil 645 & 5.57 & $1.00: 0.57: 0.3$ \\
\hline $\mathrm{RhMnLiA} / \mathrm{SiO}_{2}$ & Davisil 645 & 5.57 & $1.00: 0.57: 0.3$ \\
\hline $\mathrm{RhMnNi} / \mathrm{SiO}_{2}$ & Davisil 645 & 5.57 & $1.00: 0.57: 0.10$ \\
\hline $\mathrm{RhMnIr} / \mathrm{SiO}_{2}$ & Davisil 645 & 5.57 & $1.00: 0.57: 0.10$ \\
\hline $\mathrm{RhMnIrA} / \mathrm{SiO}_{2}$ & Davisil 645 & 5.57 & $1.00: 0.57: 0.10$ \\
\hline $\mathrm{RhMnRe} / \mathrm{SiO}_{2}$ & Davisil 645 & 5.57 & $1.00: 0.57: 0.10$ \\
\hline $\mathrm{RhMnCu} / \mathrm{SiO}_{2}$ & Davisil 645 & 5.57 & $1.00: 0.57: 0.10$ \\
\hline $\mathrm{RhMnCo} / \mathrm{SiO}_{2}$ & Davisil 645 & 5.57 & $1.00: 0.57: 0.10$ \\
\hline (a) Sample tested in previous screening tests (Gerber et al. 2007). \\
\hline \multicolumn{4}{|l}{} \\
\hline
\end{tabular}

All catalysts but one $\left(\mathrm{RhMnFe} / \mathrm{SiO}_{2} \mathrm{~B}\right)$ used Davisil 645 high surface-area $\mathrm{SiO}_{2}$ as the support and a two-step impregnation procedure using the incipient wetness technique. The silica was pretreated by calcining at $500^{\circ} \mathrm{C}$ for 2 hours (ramping up at $5^{\circ} \mathrm{C} / \mathrm{min}$ during heating and ramping down at $10^{\circ} \mathrm{C} / \mathrm{min}$ during cooling). The appropriate quantities of a rhodium nitrate solution (10 $\mathrm{wt} \% \mathrm{Rh}$ concentration in solution) and magnesium nitrate tetrahydrate were combined with enough deionized water to bring the total volume of the impregnation solution to the water adsorption pore volume of the support. The solution was impregnated onto the silica in drop-wise fashion and then dried overnight at $110^{\circ} \mathrm{C}$. A second impregnation was performed in a similar manner using an aqueous solution of the nitrate salt of the desired metal promoter followed by drying overnight at $110^{\circ} \mathrm{C}$. The dried catalyst was calcined at $400^{\circ} \mathrm{C}$ in air using a muffle furnace. The preparation of the $\mathrm{RhMnFe} / \mathrm{SiO}_{2} \mathrm{~B}$ catalyst used Davisil $150 \mathrm{LC}$ 
$\mathrm{SiO}_{2}$ as the support and used a single impregnation consisting of an aqueous solution of $\mathrm{Rh}, \mathrm{Mn}$, and $\mathrm{Fe}$ nitrate salts. The $\mathrm{RhMn} / \mathrm{SiO}_{2} \mathrm{~A}$ catalyst also consisted of a single impregnation because no additional metals were added to the catalyst. For identification, the $\mathrm{RhMn} / \mathrm{SiO}_{2} \mathrm{~A}$ and $\mathrm{RhMnFe} / \mathrm{SiO}_{2} \mathrm{~A}$ were the catalysts tested in the original screening tests reported by Gerber et al. (2007) and used a different master batch of uncalcined $\mathrm{RhMn} / \mathrm{SiO}_{2}$ catalyst. Before the tests were conducted, the calcined catalysts were loaded into the reactor and reduced using a $10 \% \mathrm{H}_{2}$ in $\mathrm{N}_{2}$ gas mixture. The $\mathrm{RhMn} / \mathrm{SiO}_{2}, \mathrm{RhMnFe} / \mathrm{SiO}_{2}$, $\mathrm{RhMnFe} / \mathrm{SiO}_{2} \mathrm{~A}, \mathrm{RhMnFe} / \mathrm{SiO}_{2} \mathrm{~B}$, and $\mathrm{RhMnLi} / \mathrm{SiO}_{2}$ catalysts were heated in the reducing atmosphere to $220^{\circ} \mathrm{C}$ at $2.5^{\circ} \mathrm{C} / \mathrm{min}$, held at that temperature for 1 hour, and then heated from $220^{\circ}$ to $260^{\circ} \mathrm{C}$ at $1{ }^{\circ} \mathrm{C} / \mathrm{min}$ and held at that temperature overnight. All other catalysts were heated in the reducing atmosphere to $220^{\circ} \mathrm{C}$ at $2.5^{\circ} \mathrm{C} / \mathrm{min}$ and held that temperature for 1 hour, heated from $220^{\circ} \mathrm{C}$ to $260^{\circ} \mathrm{C}$ at $1{ }^{\circ} \mathrm{C} / \mathrm{min}$ and held at that temperature for 8 hours, then heated to $350^{\circ} \mathrm{C}$ at $1.5^{\circ} \mathrm{C} / \mathrm{min}$ and held at that temperature for 2 hours. The $\mathrm{RhMnLiA} / \mathrm{SiO}_{2}$ and $\mathrm{RhMnIrA} / \mathrm{SIO}_{2}$ catalysts were the same formulations as the $\mathrm{RhMnLi} / \mathrm{SiO}_{2}$ and $\mathrm{RhMnIr} / \mathrm{SIO}_{2}$ catalysts, but were tested under alternative catalyst reduction or reactor heating methods.

\subsection{Testing Procedure}

During a typical test series, a catalyst was loaded into the reactor and its net weight determined. The reactor was placed in the reactor system and reduced in place at atmospheric pressure. The reactor was cooled after catalyst reduction, and the desired syngas feed rate and pressure were established. The reactor was heated slowly to a temperature at which the reaction rate was significant (nominally $255^{\circ} \mathrm{C}$ ) and kept there for at least 24 hours to allow the catalyst to age. The product stream was directed through the bypass line cold trap during this time. After aging the catalyst, the product stream was redirected through the other cold trap for a period sufficient for at least 10 bed volumes of gas feed (based on the operating pressure and dry product gas flow rate) to pass through the cold trap. This period of time provides a representative gas sample and a sufficiently large liquid sample for subsequent analysis. The operating conditions were recorded before sampling with two or more grab samples of product gas obtained and analyzed in a gas chromatograph (GC) along with a feed gas sample and a calibration gas sample. The liquid recovered from the cold trap was weighed and, if two phases were present, separated into aqueous and organic phases. The weighed organic phase was not analyzed and was assumed to have a composition comparable to hexane for purposes of a carbon balance. The weighed aqueous phase was analyzed using a high-pressure liquid chromatograph (HPLC) to quantify the $\mathrm{C}_{1}-\mathrm{C}_{5}$ oxygenates (principally alcohols, acids, aldehydes, esters, and any other significant peaks identified by the HPLC). After sampling, a new set of conditions (temperature and feed rate) was established and another cold trap sample collected at the new conditions. This procedure was repeated until a representative set of conditions was obtained to evaluate catalyst performance in terms of STY, carbon selectivity, and singlepass carbon conversion. In most cases, tests advanced to progressively higher temperatures with one or more space velocities examined during each test. Except where noted, tests were conducted at nominal temperatures of $255^{\circ}, 275^{\circ}, 300^{\circ}$, and $/$ or $325^{\circ} \mathrm{C}$, with some additional tests conducted at $\sim 315^{\circ} \mathrm{C}$. Tests at $255^{\circ}$ and $275^{\circ} \mathrm{C}$ used a space velocity of $7,500 \mathrm{~L} / \mathrm{L}_{\text {cat }} / \mathrm{hr}$, while tests conducted at higher temperatures used a space velocity of $11,000 \mathrm{~L} / \mathrm{L}_{\text {cat }} / \mathrm{hr}$ to try to maintain carbon conversions below $50 \%$, because past experience has shown that higher conversions usually result in lower $\mathrm{C}_{2}{ }^{+}$oxygenate STYs for this class of catalysts. In some tests, previous lower temperature conditions were re-examined to determine whether further catalyst aging during testing affected the performance of the catalyst. 
To calculate a representative average outlet flow rate during a sample collection period, a nitrogen balance was used with the calibrated feed flow rates. The product gas flow rate downstream of the cold trap was monitored and recorded for estimating the product gas flow rate and to provide a rough check on the accuracy of the calculated flow using a nitrogen balance. Carbon balances using this method were approximately $\pm 10 \%$. 


\subsection{Reactor System Performance}

During earlier testing it was determined that the measured outlet flow rate at a particular point in time was not always representative of the average flow rate during liquid sample collection in the cold trap because of slow fluctuations over irregular periods of several minutes to several hours. These fluctuations are attributed to mass flow controller flow rate oscillations, relatively small fluctuations in the reactor pressure, and transient changes in catalyst reactivity. Flow rate was measured four or more times over a period of approximately 1 hour prior to sampling and averaged to mitigate the effects of the mass flow controller. The back-pressure regulator was wrapped with a heat tape and maintained at a constant temperature $\left(35^{\circ} \mathrm{C}\right)$ to minimize pressure fluctuations, once it was determined that the temperature sensitivity of the back-pressure regulator was the likely cause of periodic pressure changes.

Longer periods of temperature fluctuation were found to occur during testing that were attributed to the behavior of the catalyst. Some of the change could be attributed to slow deactivation of the catalyst that appeared to be more pronounced at temperatures above $325^{\circ} \mathrm{C}$. However, it was also found that when the more reactive catalysts were operated at reaction rates that approached the limits of the reactor furnace to remove excess heat, small changes in reactor temperature could cause large fluctuations in the catalyst bed temperature. These excursions lasted anywhere from a few hours to a half a day and in some cases produced a periodic temperature cycle that ranged as much as $40^{\circ} \mathrm{C}$ over time. This phenomenon has been reported in the literature for Fischer-Tropsch Catalysts (Tsotsis et al. 1982). If temperature fluctuations could be maintained within a $\sim 12^{\circ} \mathrm{C}$ temperature range for a sufficiently long period of time then data was collected and a sample was taken, using the average catalyst temperature during the sampling period as the basis for performance comparison to other catalysts. If temperature fluctuations were too great, then a different set of conditions was sought that could produce acceptable temperature fluctuations. Consequently, all temperatures were not evaluated when the furnace was used. By switching to reactor heating with a hot oil circulating system, which was more efficient at excess heat removal, catalyst temperatures excursions were reduced to a couple of degrees and all temperatures could be evaluated. 


\subsection{Test Results}

The primary objective of the second set of tests is to determine whether promoters other than Fe could produce favorable improvements in the performance of the $\mathrm{RhMn} / \mathrm{SiO}_{2}$ catalyst in terms of $\mathrm{C}_{2}{ }^{+}$oxygenate STY, carbon selectivity to $\mathrm{C}_{2}{ }^{+}$oxygenates and carbon selectivity to $\mathrm{C}_{2}{ }^{+}$alcohols. The results of these tests are shown in the appendix. At the same time, some additional tests were conducted to examine minor variations in the catalyst preparation and reduction procedure to ensure that these variations would not have a significant effect on the comparison of different promoters. In addition, a change in the method of heating the catalyst was made during testing to provide better control of the catalyst temperature during testing to make comparisons of the catalysts more consistent.

\subsection{Examination of Catalyst Preparation Techniques}

Before examining the effect of other promoters, two $\mathrm{RhMn} / \mathrm{SiO}_{2}$ catalysts that used Fe as a promoter were tested this year (FY 2007). The first catalyst $\left(\mathrm{RhMnFe} / \mathrm{SiO}_{2}\right)$ was prepared in the same manner as the catalyst that was tested during the initial catalyst screening except that a new batch of the base catalyst was used. The purpose of the testing was to verify that the two batches of $\mathrm{Rh} / \mathrm{Mn} / \mathrm{SiO}_{2}$ catalysts behaved similarly. Details of the performance of the previously screened catalysts were reported by Gerber et al. (2007). The second catalyst $\left(\mathrm{RhMn} / \mathrm{SiO}_{2} \mathrm{~B}\right)$ had the same composition as the other two catalysts except that the support was Davisil LC150 silica instead of Davisil 645 silica, and the Fe precursor was coimpregnated with the $\mathrm{Rh}$ and $\mathrm{Mn}$ precursors in a single impregnation. The previous two catalysts were co-impregnated with the Rh and Mn precursors and the catalyst dried before a adding the Fe in a second impregnation. All of the tests were conducted using the furnace to heat the catalysts. Also, gas mixtures evaluated ranged from 1.8 to $2.0 \mathrm{H}_{2}$ : $\mathrm{CO}$ ratio for those tested using a low-ratio feed gas, and from 2.3 to $2.6 \mathrm{H}_{2}$ : $\mathrm{CO}$ ratio for those tests using a high-ratio feed gas. The two different ranges of gas composition were used to compare data obtained in earlier screening tests. Figures 4.1 and 4.2 compare the $\mathrm{C}_{2}{ }^{+}$ oxygenate STYs and carbon selectivities, respectively, for the three Fe promoted catalysts. It appears that there are no significant differences in the $\mathrm{C}_{2}{ }^{+}$oxygenate STYs or selectivities of the three catalysts with respect to the silica support and the method of preparation. The $\mathrm{H}_{2}$ : $\mathrm{CO}$ ratio also does not appear to have a significant effect on either the STYs or carbon selectivities to $\mathrm{C}_{2}+$ oxygenates. Based on these results, all other catalysts were prepared by adding the desired promoter to a master batch of $\mathrm{RhMn} / \mathrm{SiO}_{2}$ that used the Davisil 645 silica as the support.

\subsection{Examination of the Catalyst Reduction Temperature}

After completion of the tests using $\mathrm{Fe}$ as a promoter, the $\mathrm{Li}$ promoted catalyst was tested twice ( $\mathrm{RhMnLi} / \mathrm{SiO}_{2}$ and $\mathrm{RhMnLi} / \mathrm{SiO}_{2} \mathrm{~A}$ ), because it appeared that temperature excursions above $325^{\circ} \mathrm{C}$ during the first test cause a reduction in the activity of the catalyst, but an improvement in carbon selectivity to alcohols as well as a reduction in the production of higher hydrocarbons.

During the first catalyst test, samples were collected for catalyst temperature conditions of 256, 277, and $302^{\circ} \mathrm{C}$ (two sets of samples). When the furnace temperature was increase following collection of the fourth sample a temperature excursion of $80^{\circ}-90^{\circ} \mathrm{C}$ occurred that remained above 375 for 3 hours and then slowly cooled to $344^{\circ} \mathrm{C}$ over the next 18 hours. An attempt to raise the temperature to $350^{\circ} \mathrm{C}$ was 


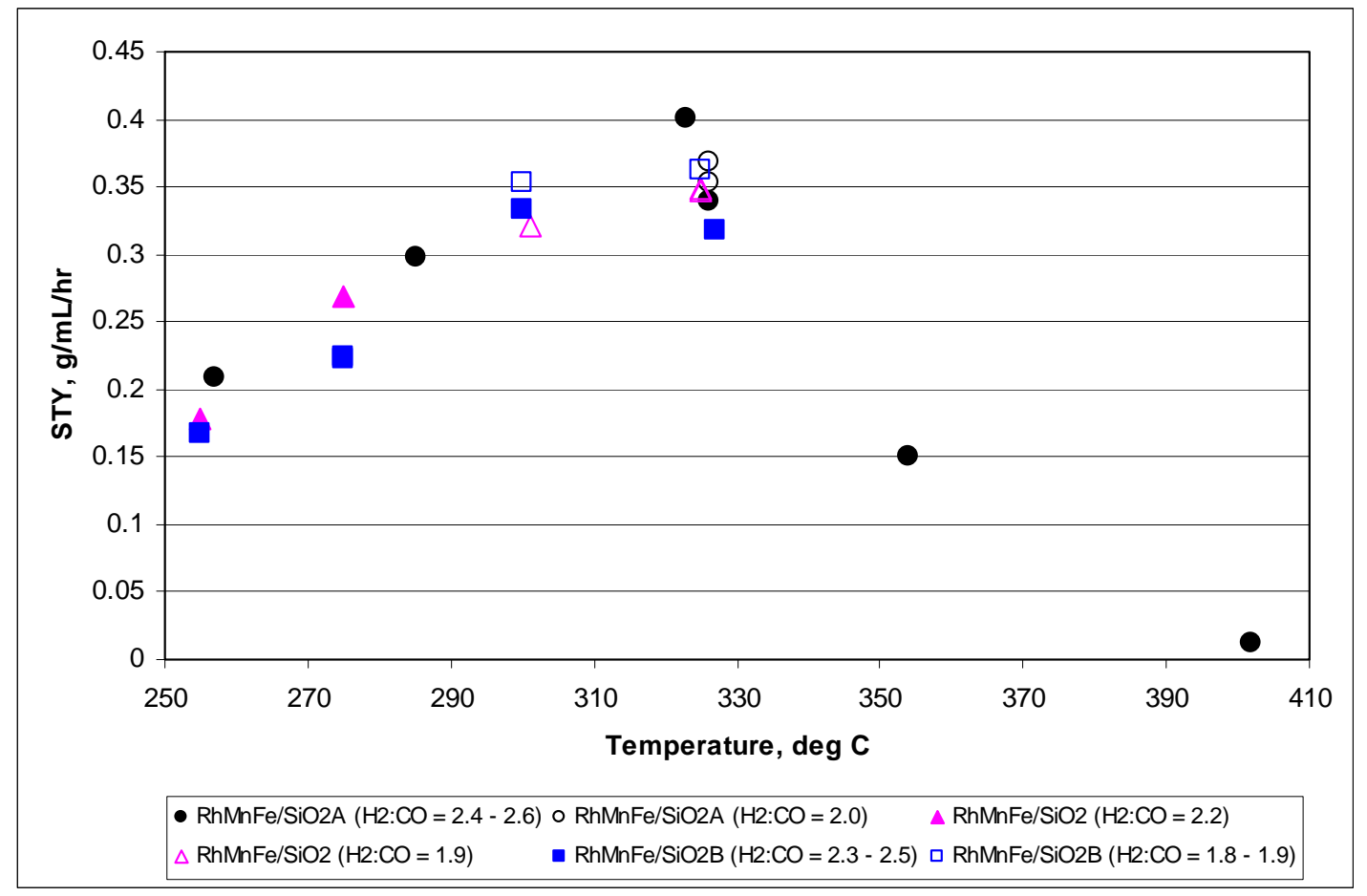

Figure 4.1. $\mathrm{C}_{2}^{+}$Oxygenate STYs for Iron-Promoted Catalysts

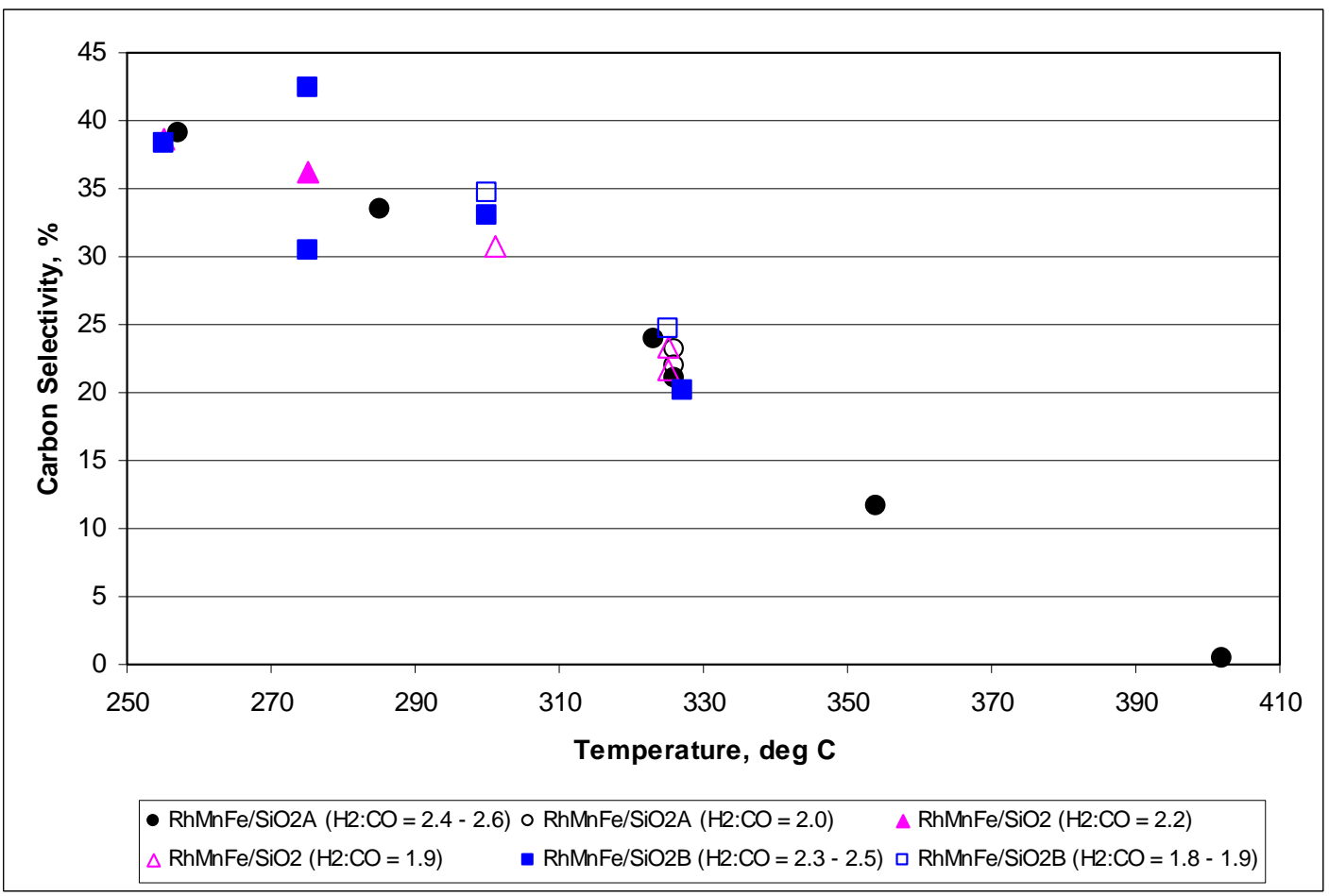

Figure 4.2. Carbon Selectivities to $\mathrm{C}_{2}^{+}$Oxygenates for Iron-Promoted Catalysts 
then attempted, and the temperature remained there for 7 hours before abruptly dropping to $297^{\circ} \mathrm{C}$. The catalyst temperature was stabilized at $\sim 292^{\circ} \mathrm{C}$ long enough to collect a representative sample and associated set of data. It was clear from the quantity of liquid in this sample that the catalyst had deactivated, so two additional test conditions were obtained at $326^{\circ}$ and $350^{\circ} \mathrm{C}$ to examine the performance of the deactivated catalyst. The second catalyst was tested similarly to the first catalyst prior its temperature excursion to examine whether reducing the catalyst at a higher temperature reduced the activity of the catalyst. A $350^{\circ} \mathrm{C}$ maximum reduction temperature was selected because the Fe promoted catalysts experienced decreases in the liquid hydrocarbon yield at catalyst temperatures at or above $300^{\circ} \mathrm{C}$.

Figures 4.3 and 4.4 show the effect of temperature on the carbon conversions and STYs of both catalysts. It can be seen that both carbon conversion and $\mathrm{C}_{2}+$ oxygenate STYs decreased following the temperature excursion indicative of catalyst deactivation. However, it was possible to bring carbon conversion to pre-temperature excursion levels at a higher temperature $\left(350^{\circ}\right.$ versus $\sim 300^{\circ} \mathrm{C}$ prior to the temperature excursion) although the $\mathrm{C}_{2}+$ oxygenate STYs were about $20 \%$ lower than before for the same carbon conversion. Reducing the catalyst at a higher temperature appeared to have a slightly negative effect on carbon conversion and $\mathrm{C}_{2}{ }^{+}$oxygenate STYs at temperatures up to $\sim 300^{\circ} \mathrm{C}$. Unlike previous catalysts, carbon conversion did not appear to be affected by the space velocity for either Li-promoted catalyst.

Interestingly, the $\mathrm{C}_{2}{ }^{+}$oxygenate carbon selectivity trend with temperature for the catalyst before and after the temperature excursion remained the same according to Figure 4.5. On the other hand, the $\mathrm{C}_{2}{ }^{+}$ alcohols accounted for a significantly greater portion of the total oxygenates after the temperature excursion, as shown in Figure 4.6. Reducing the catalyst at a higher temperature did not have a significant effect on the carbon selectivity to $\mathrm{C}_{2}{ }^{+}$oxygenates and had a slightly positive effect on the portions of the oxygenates that were $\mathrm{C}_{2}{ }^{+}$alcohols.

Another observation was the effect of temperature on the carbon selectivities to various hydrocarbons. Figure 4.7 shows that, following the temperature excursion, the carbon selectivity to hydrocarbon liquids was eliminated and the selectivity to $\mathrm{C}_{2}-\mathrm{C}_{5}$ hydrocarbon gases was diminished even at the higher catalyst temperatures when the total carbon selectivity to hydrocarbons was as high as $60 \%$. When taken together with the carbon selectivity to $\mathrm{C}_{2}{ }^{+}$oxygenate trend, which was not affected by the temperature excursion (Figure 4.5), it appears that the excursion altered the carbon chain-growth mechanism for hydrocarbons but not the chain-growth mechanism for oxygenates. This suggests that different catalyst sites are responsible for $\mathrm{C}_{2}{ }^{+}$hydrocarbon and $\mathrm{C}_{2}{ }^{+}$oxygenate synthesis. Reducing the catalyst at a higher temperature appeared to result in a slight reduction in the carbon selectivity to higher hydrocarbons, as shown in Figure 4.7.

Overall it appeared that increasing the reducing temperature of the catalyst resulted in relatively minor negative effects on catalyst performance in terms of carbon conversion, $\mathrm{C}_{2}{ }^{+}$oxygenate STYs; no effect on carbon selectivity to $\mathrm{C}_{2}{ }^{+}$oxygenates; and significant positive effects in terms of higher ratio of $\mathrm{C}_{2}^{+}$alcohols to total oxygenates and reduced production of higher hydrocarbons. Based on these results, subsequent testing used the higher reduction temperature procedure. 


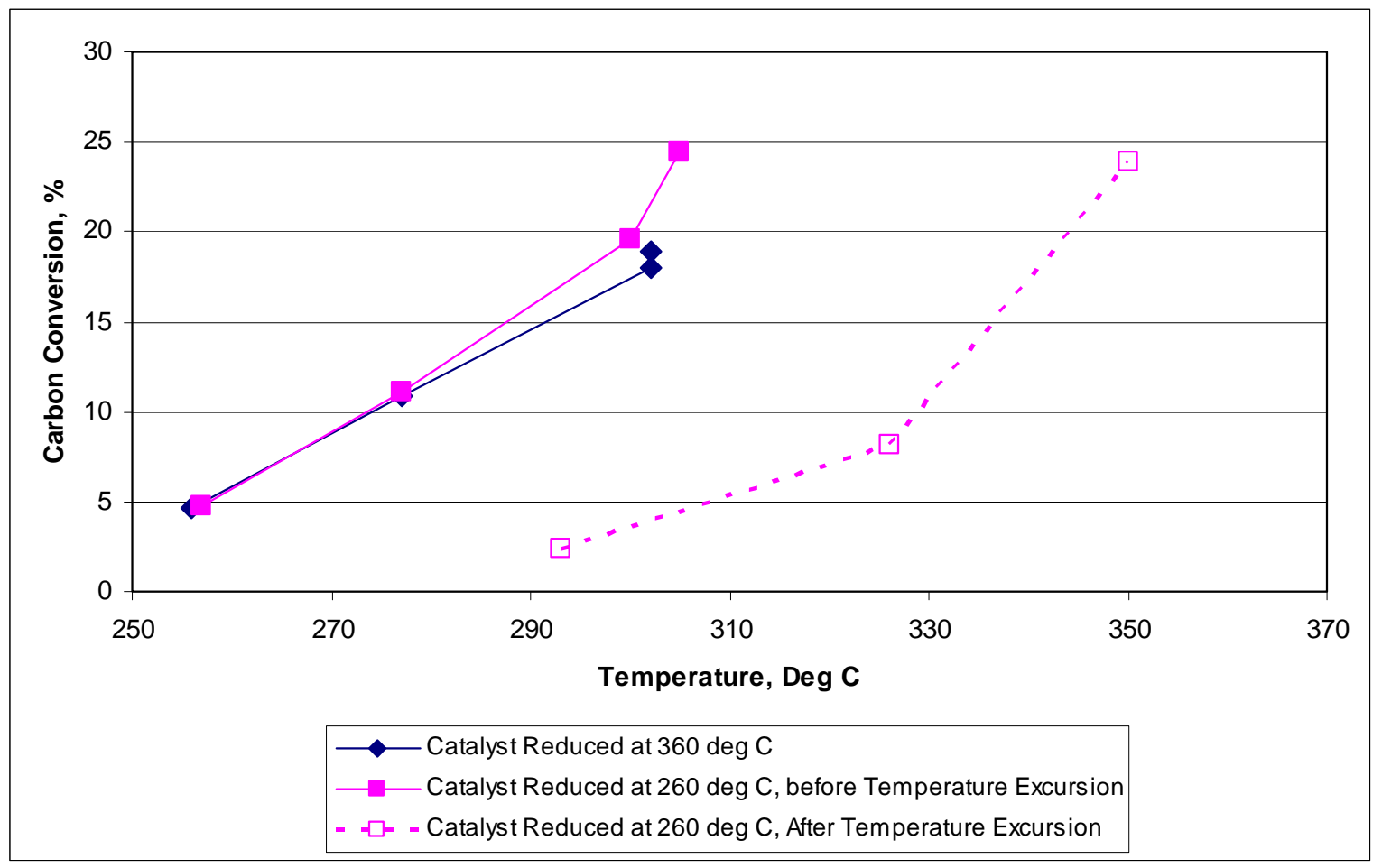

Figure 4.3. Carbon Conversion of Li-Promoted Catalysts

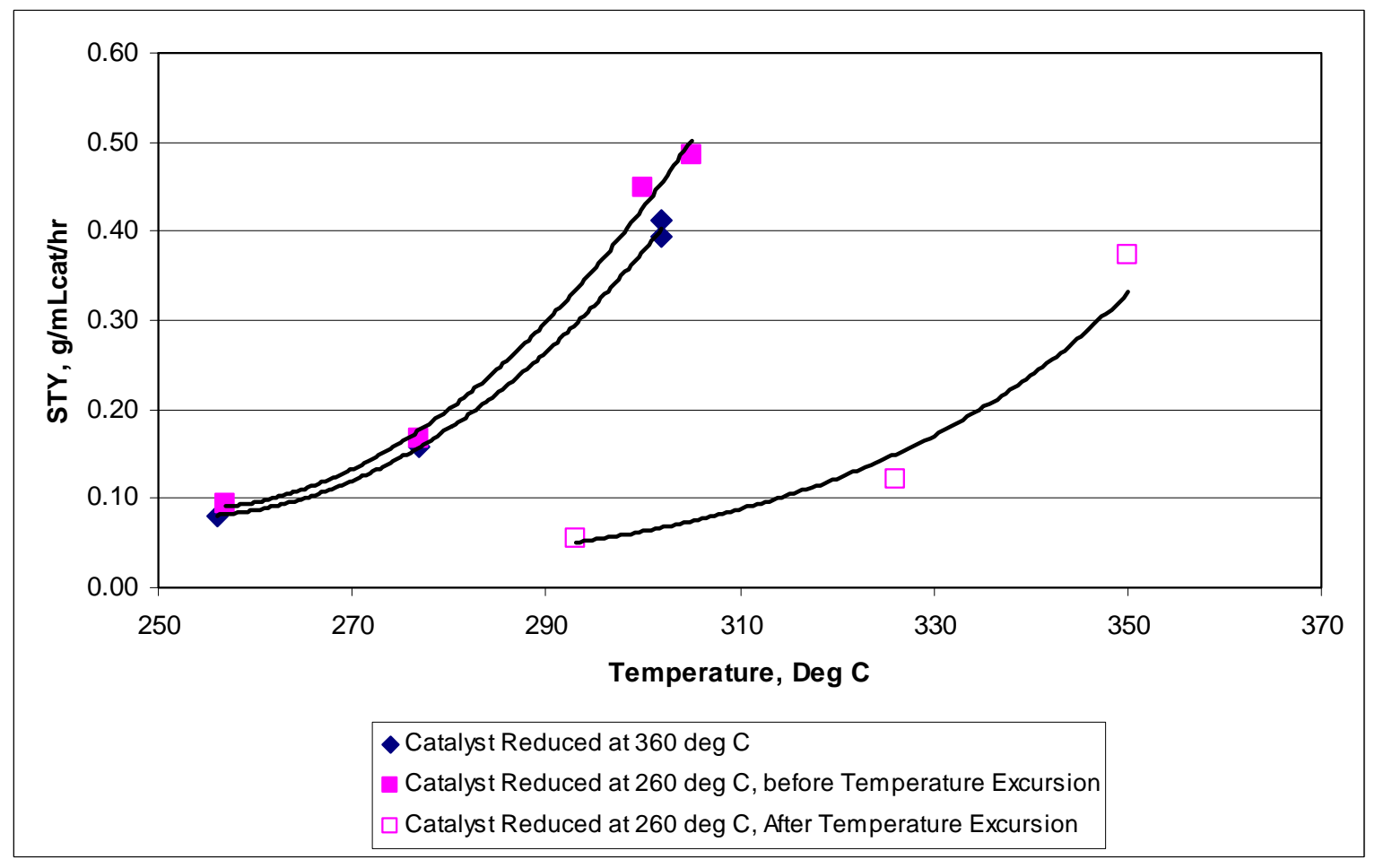

Figure 4.4. $\mathrm{C}_{2}^{+}$Oxygenate STYs for Li-Promoted Catalysts 


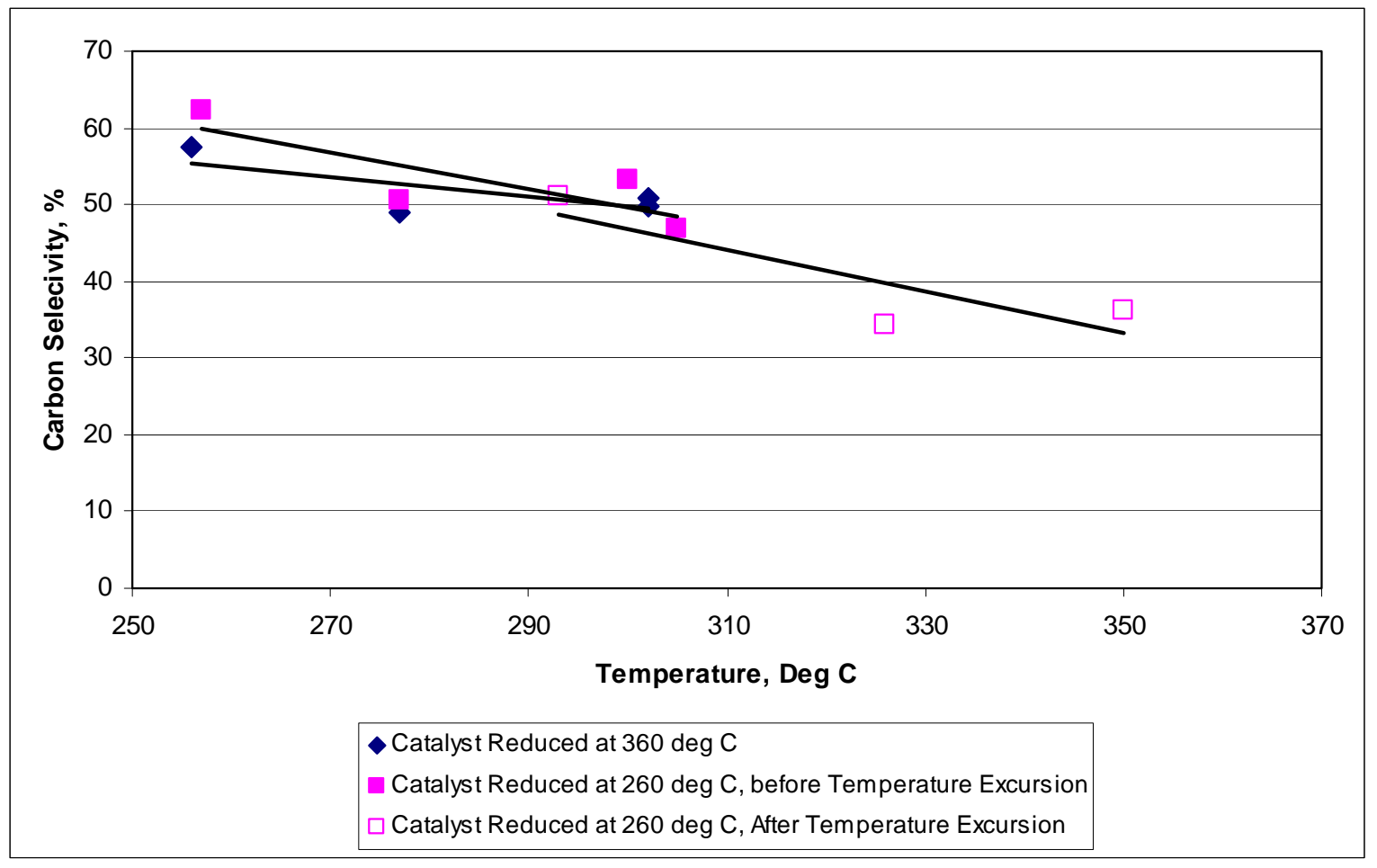

Figure 4.5. Carbon Selectivity to $\mathrm{C}_{2}^{+}$Oxygenates for Li-Promoted Catalysts

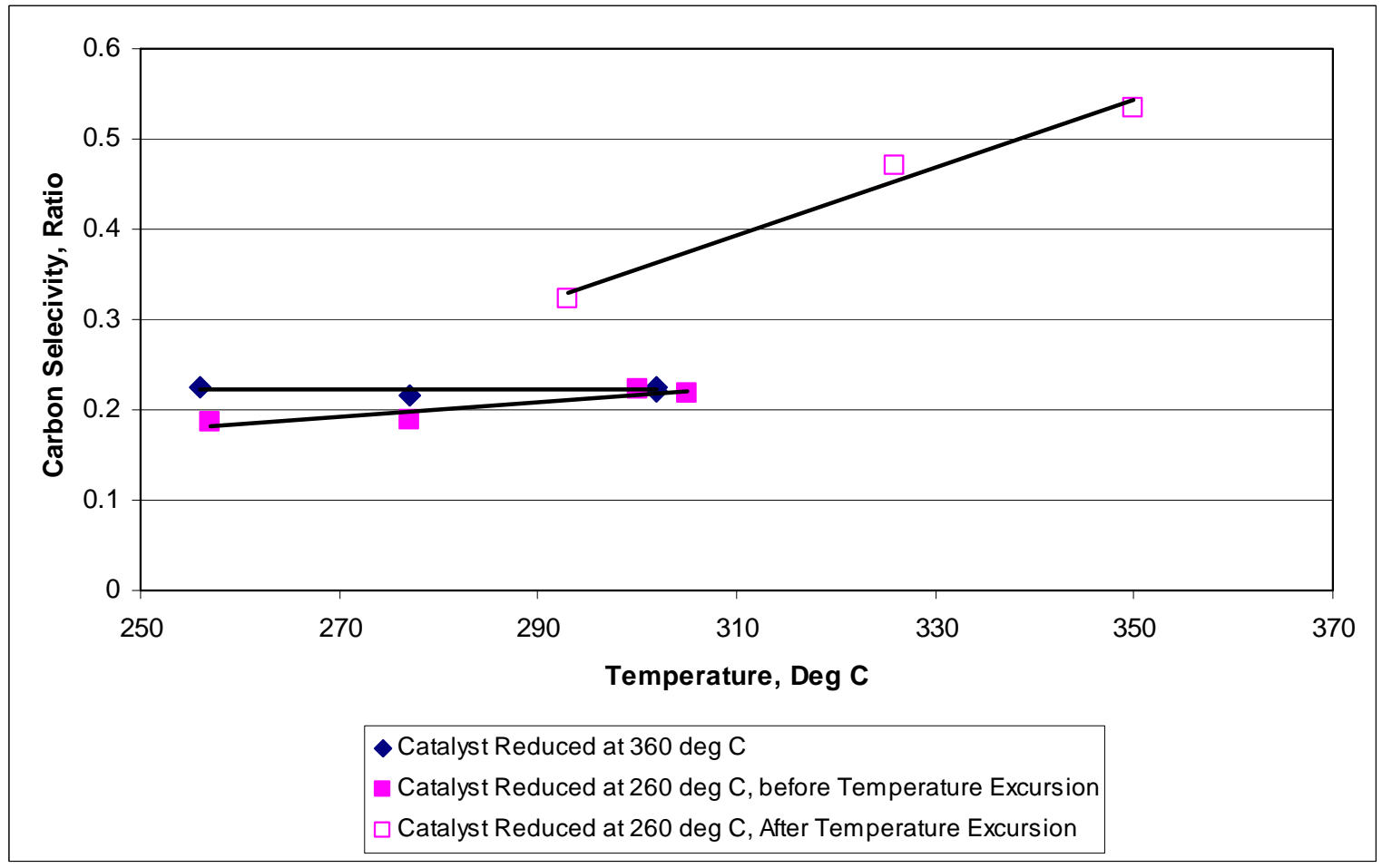

Figure 4.6. Carbon Selectivity of All Oxygenates to $\mathrm{C}_{2}{ }^{+}$Alcohols for Li-Promoted Catalysts 


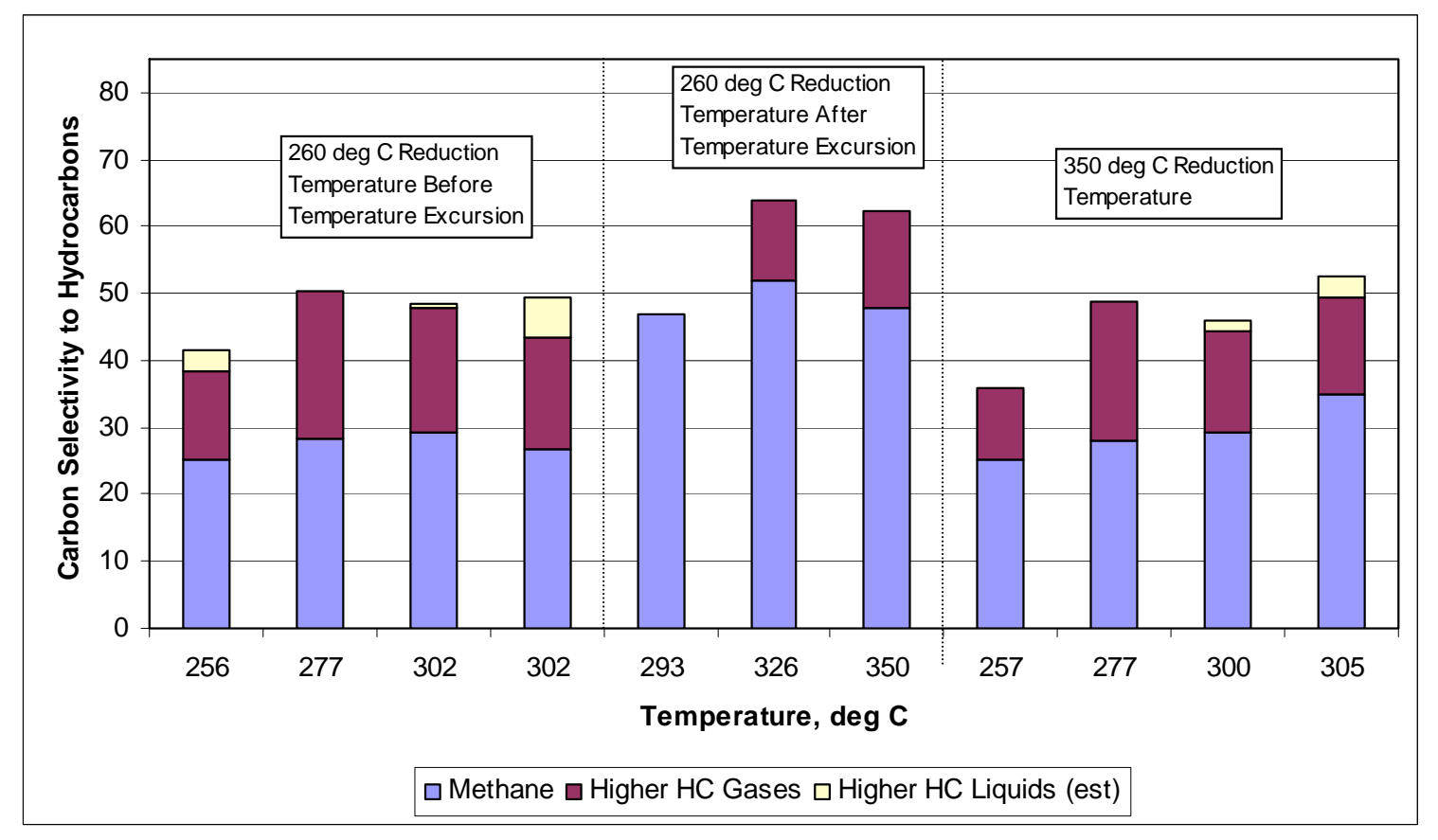

Figure 4.7. Comparison of Hydrocarbon Selectivities for Li-Promoted Catalysts

\subsection{Evaluation of Catalyst Heating Method}

After the Ni- and Ir-promoted catalysts were tested, the Ir-promoted catalyst was tested a second time $\left(\mathrm{RhMnIr} / \mathrm{SiO}_{2} \mathrm{~A}\right)$ using a hot oil circulating system to heat the reactor instead of the furnace. Up to this point, it had always been difficult to control the catalyst temperature at temperatures above $275^{\circ} \mathrm{C}$. With the Ir-promoted catalyst, temperature control became a problem above $255^{\circ} \mathrm{C}$ using the furnace. Using the hot circulating oil system it was possible to control the temperature of the catalyst at the higher temperatures. All subsequent testing with the other promoted catalysts was performed using the hot oil circulator to take advantage of its ability to minimize temperature excursions.

\subsection{Comparison of the Effects of Promoters on Catalyst Performance}

The previous set of tests to screen different classes of mixed alcohols synthesis catalysts showed that the $\mathrm{RhMn} / \mathrm{SiO}_{2}\left(\mathrm{RhMn} / \mathrm{SiO}_{2} \mathrm{~A}\right)$ and the $\mathrm{RhMnFe} / \mathrm{SiO}\left(\mathrm{RhMnFe} / \mathrm{SiO}_{2} \mathrm{~A}\right)$ catalysts had the best combination of relatively high selectivity to $\mathrm{C}_{2}{ }^{+}$oxygenates and high $\mathrm{C}_{2}{ }^{+}$oxygenate STYs. Furthermore it appeared that adding Fe to the $\mathrm{RhMn} / \mathrm{SiO}_{2}$ catalyst improved the $\mathrm{C}_{2}{ }^{+}$oxygenate STYs and possibly the carbon yield of $\mathrm{C}_{2}^{+}$alcohols. This set of tests was conducted to examine the potential for other promoters to improve the $\mathrm{C}_{2}{ }^{+}$oxygenate STY, carbon selectivity to $\mathrm{C}_{2}{ }^{+}$oxygenates, and carbon selectivity of $\mathrm{C}_{2}{ }^{+}$alcohols relative to the carbon yield of all oxygenates in the aqueous phase product, the latter an indication of the purity of the aqueous product containing the $\mathrm{C}_{2}{ }^{+}$alcohols.

For comparison, promoters were compared at two conditions: 1 ) highest $\mathrm{C}_{2}{ }^{+}$oxygenate STY and 2) highest carbon selectivity to $\mathrm{C}_{2}{ }^{+}$oxygenates, recognizing that these conditions could be achieved at different testing conditions (temperature and space-velocity) for each catalyst. Table 4.1 summarizes the 
Table 4.1. Summary of Test Results at Conditions for Maximum $\mathrm{C}_{2}^{+}$Oxygenate STYs and Carbon Selectivity of $\mathrm{C}_{2}^{+}$Oxygenates $^{+}$

\begin{tabular}{|c|c|c|c|c|c|c|c|c|c|c|c|c|c|}
\hline \multirow[b]{2}{*}{ Test Cond. } & \multirow[b]{2}{*}{ Catalyst } & \multirow[b]{2}{*}{$\begin{array}{c}\text { Space } \\
\text { Velocity } \\
\text { (L/L/hr) }\end{array}$} & \multirow[b]{2}{*}{$\begin{array}{c}\text { Temp. } \\
\left({ }^{\circ} \mathrm{C}\right)\end{array}$} & \multicolumn{3}{|c|}{ STY (g/mL cat $\left._{\text {cat }} / \mathbf{h r}\right)$} & \multicolumn{7}{|c|}{ Carbon Selectivity (C-Mol\%) } \\
\hline & & & & $\begin{array}{c}\text { Carbon } \\
\text { Conv. } \\
(\%)\end{array}$ & $\begin{array}{c}\mathrm{C}_{2}^{+} \\
\text {Alcohols }\end{array}$ & $\begin{array}{c}\text { Total C }_{2}^{+} \\
\text {Oxygenates }\end{array}$ & $\begin{array}{c}\mathrm{C} 1 \\
\text { Oxygenates }\end{array}$ & $\begin{array}{c}\mathrm{C}_{2}^{+} \\
\text {Alcohols }\end{array}$ & $\begin{array}{c}\text { Total } \mathrm{C}_{2}^{+} \\
\text {Oxygenates }\end{array}$ & Methane & \begin{tabular}{|c|} 
Higher \\
HC \\
Gases
\end{tabular} & \begin{tabular}{|c} 
Higher \\
HC \\
Liquids \\
(est)
\end{tabular} & $\begin{array}{c}\text { Carbon } \\
\text { Selectivity to } \\
\text { C+ Alcohols } \\
\text { vs. All } \\
\text { Oxygenates }\end{array}$ \\
\hline \multirow{7}{*}{$\begin{array}{l}\text { Maximum } \\
\mathrm{C}_{2}^{+} \\
\text {Oxygenate } \\
\text { STYs }\end{array}$} & $\mathrm{Rh} / \mathrm{Mn} / \mathrm{Fe} / \mathrm{Al}_{2} \mathrm{O}_{3}$ & 11000 & 323 & 47 & 0.270 & 0.401 & \begin{tabular}{|l|}
0.4 \\
\end{tabular} & 16.6 & 23.9 & 58.87 & 16.76 & 0.00 & 68.006 \\
\hline & RhMnLiA & 11000 & 305 & 24 & 0.099 & 0.485 & 0.4 & 10.3 & 46.9 & 34.90 & 14.66 & 3.14 & 21.824 \\
\hline & RhMnNi & 11000 & 325 & 34 & 0.169 & 0.476 & 0.0 & 11.9 & 32.5 & 56.10 & 11.26 & 0.18 & 36.545 \\
\hline & RhMnIrA & 15000 & 325 & 38 & 0.210 & 0.805 & 0.2 & 10.2 & 38.6 & 46.66 & 13.52 & 0.99 & 26.402 \\
\hline & RhMnRe & 11000 & 324 & 38 & 0.15 & 0.26 & 0.4 & 9.7 & 31.6 & 62.07 & 17.08 & 4.63 & 59.96 \\
\hline & $\mathrm{RhMnCu}$ & 11000 & 315 & 9 & 0.07 & 0.15 & 2.2 & 18.8 & 37.7 & 54.82 & 5.26 & 0.00 & 46.99 \\
\hline & RhMnCo & 11000 & 299 & 28 & 0.08 & 0.35 & 0.0 & 6.8 & 30.5 & 43.84 & 18.00 & 7.70 & 22.20 \\
\hline \multirow{7}{*}{$\begin{array}{l}\text { Maximum } \\
\text { Carbon } \\
\text { Selectivity } \\
\text { to } \mathrm{C}_{2}^{+} \\
\text {Oxygenates }\end{array}$} & $\mathrm{RhMnFe}^{`}$ & 7500 & 275 & 21 & 0.067 & 0.223 & 0.7 & 13.4 & 42.4 & 40.78 & 14.46 & 1.67 & 31.036 \\
\hline & RhMnLiA & 11000 & 300 & 20 & 0.092 & 0.449 & 0.7 & 12.0 & 53.3 & 29.36 & 14.96 & 1.68 & 22.245 \\
\hline & RhMnNi & 7500 & 277 & 12 & 0.044 & 0.179 & 0.0 & 13.4 & 50.7 & 36.45 & 11.50 & 1.30 & 26.403 \\
\hline & RhMnIrA & 7500 & 276 & 31 & 0.056 & 0.444 & 0.0 & 6.6 & 47.8 & 28.83 & 20.18 & 3.20 & 13.749 \\
\hline & RhMnRe & 7500 & 256 & 19 & 0.05 & 0.21 & 0.0 & 9.1 & 41.8 & 31.45 & 22.83 & 9.36 & 24.94 \\
\hline & $\mathrm{RhMnCu}$ & 7500 & 276 & 5 & 0.02 & 0.07 & 1.6 & 15.6 & 46.3 & 46.99 & 1.94 & 3.17 & 32.64 \\
\hline & RhMnCo & 7500 & 256 & 10 & 0.03 & 0.14 & 0.9 & 9.6 & 50.5 & 29.20 & 16.56 & 2.84 & 18.68 \\
\hline
\end{tabular}


test conditions and catalyst performance data for these two conditions. The results of all of the tests are shown in the appendix. Figure 4.8 shows the $\mathrm{C}_{2}{ }^{+}$oxygenate STYs for the conditions for maximum STYs. It can be seen that the Ir promoted catalyst achieved a significantly higher maximum $\mathrm{C}_{2}{ }^{+}$oxygenate STY than any of the other promoters. It was a very reactive catalyst and required a higher space velocity to realize its highest STY at $325^{\circ} \mathrm{C}\left(\sim 800 \mathrm{~g} / \mathrm{L}_{\text {cat }} / \mathrm{hr}\right)$. However, even at similar space velocities this catalyst produced a higher STY $\left(\sim 690 \mathrm{~g} / \mathrm{L}_{\text {cat }} / \mathrm{hr}\right)$ than the other catalysts. The next best catalysts were the Li- and Ni-promoted catalysts ( $\left.480 \mathrm{~g} / \mathrm{L}_{\text {cat }} / \mathrm{hr}\right)$ followed by Fe- and Co-promoted catalysts $\left(\sim 350 \mathrm{~g} / \mathrm{L}_{\text {cat }} / \mathrm{hr}\right)$. Under conditions achieving maximum $\mathrm{C}_{2}{ }^{+}$oxygenate STYs, the Li-promoted catalyst had the best selectivity at $\sim 47 \%$, as shown in Figure 4.9 , followed by Ir and $\mathrm{Cu}$ promoters at $\sim 39$ and 38\%, respectively, and $\mathrm{Co}$ and $\mathrm{Ni}$ at $\sim 30-32 \%$, respectively. Base on these results, the Ir- and Li-promoted catalysts had the best balance of high $\mathrm{C}_{2}^{+}$oxygenate STYs and carbon selectivity to $\mathrm{C}_{2}^{+}$oxygenates, followed by Ni.

Generally, conditions favoring selectivity to $\mathrm{C}_{2}{ }^{+}$oxygenates occurred at the lower temperature for each catalyst (typically $\sim 255^{\circ}$ and $\sim 275^{\circ} \mathrm{C}$ ), where the $\mathrm{C}_{2}{ }^{+}$oxygenate STYs are relatively low. However, catalyst performances under these conditions provide additional insight into the overall behavior of the various promoters. In Figure 4.10, it can be seen that Ir continues to have a very good $\mathrm{C}_{2}^{+}$oxygenate STY ( $\left.440 \mathrm{~g} / \mathrm{L}_{\text {cat }} / \mathrm{hr}\right)$ followed by Fe $\left(\sim 220 \mathrm{~g} / \mathrm{L}_{\text {cat }} / \mathrm{hr}\right)$ and $\operatorname{Re}\left(\sim 210 \mathrm{~g} / \mathrm{L}_{\text {cat }} / \mathrm{hr}\right)$. The Li promoter, on the other hand had the highest selectivity to $\mathrm{C}_{2}^{+}$oxygenates ( 62\%), as shown in Figure 4.11, followed by $\mathrm{Co}, \mathrm{Ni}, \mathrm{Ir}$, and $\mathrm{Cu}(\sim 51,50,47$, and $46 \%$, respectively). Iridium again appears to have the best balance of higher $\mathrm{C}_{2}{ }^{+}$oxygenate STYs and carbon selectivity to $\mathrm{C}_{2}{ }^{+}$oxygenates at the lower operating temperatures. The $\mathrm{Ni}$ and Fe promoters would follow next in terms of balanced performance under these conditions.

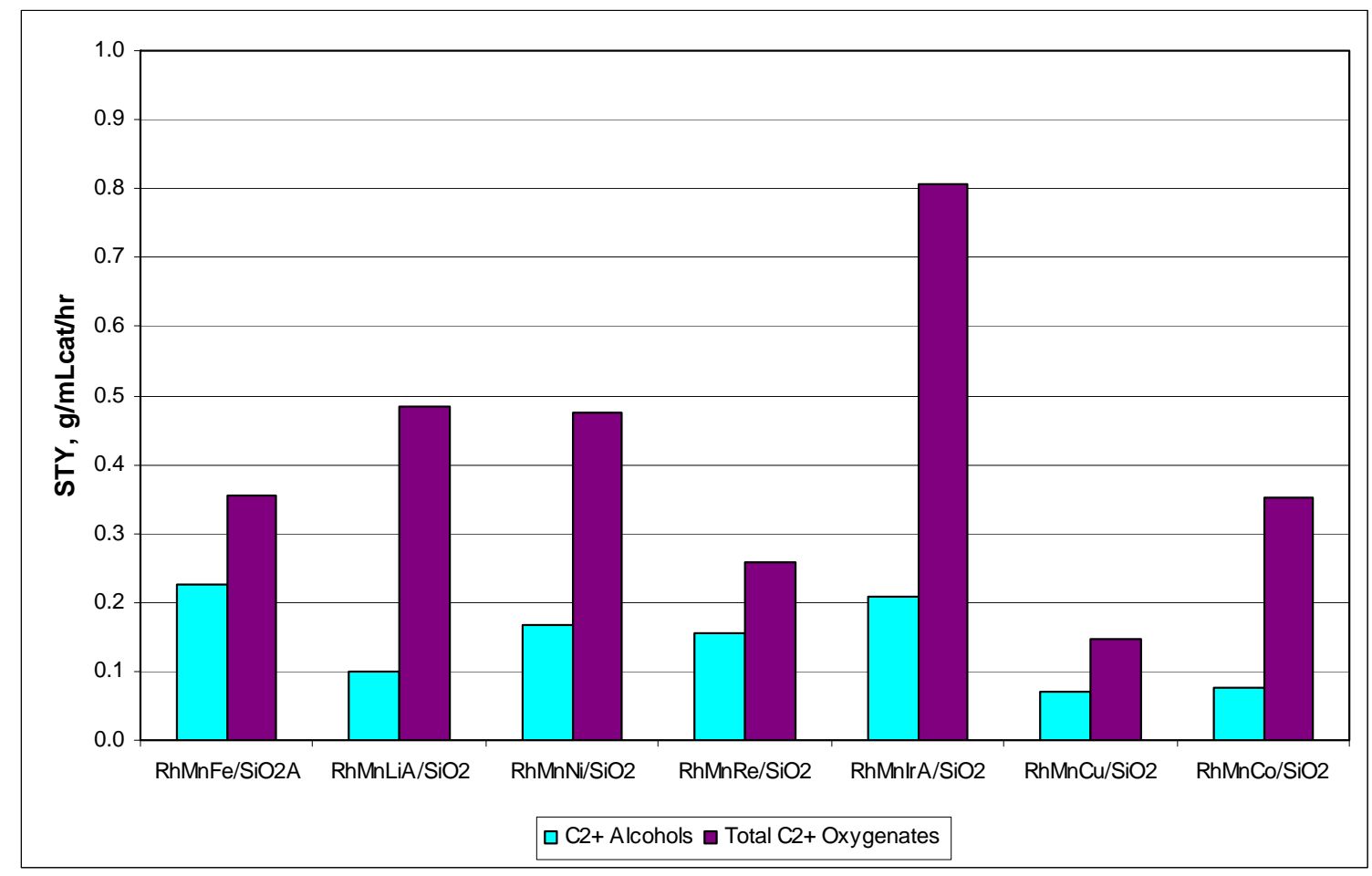

Figure 4.8. Comparison of $\mathrm{C}_{2}{ }^{+}$Alcohols and $\mathrm{C}_{2}{ }^{+}$Oxygenate $\mathrm{STYs}$ for $\mathrm{RhMn} / \mathrm{SiO}_{2}$ Catalysts with Different Promoters at Conditions Producing Maximum $\mathrm{C}_{2}^{+}$Oxygenate STYs 


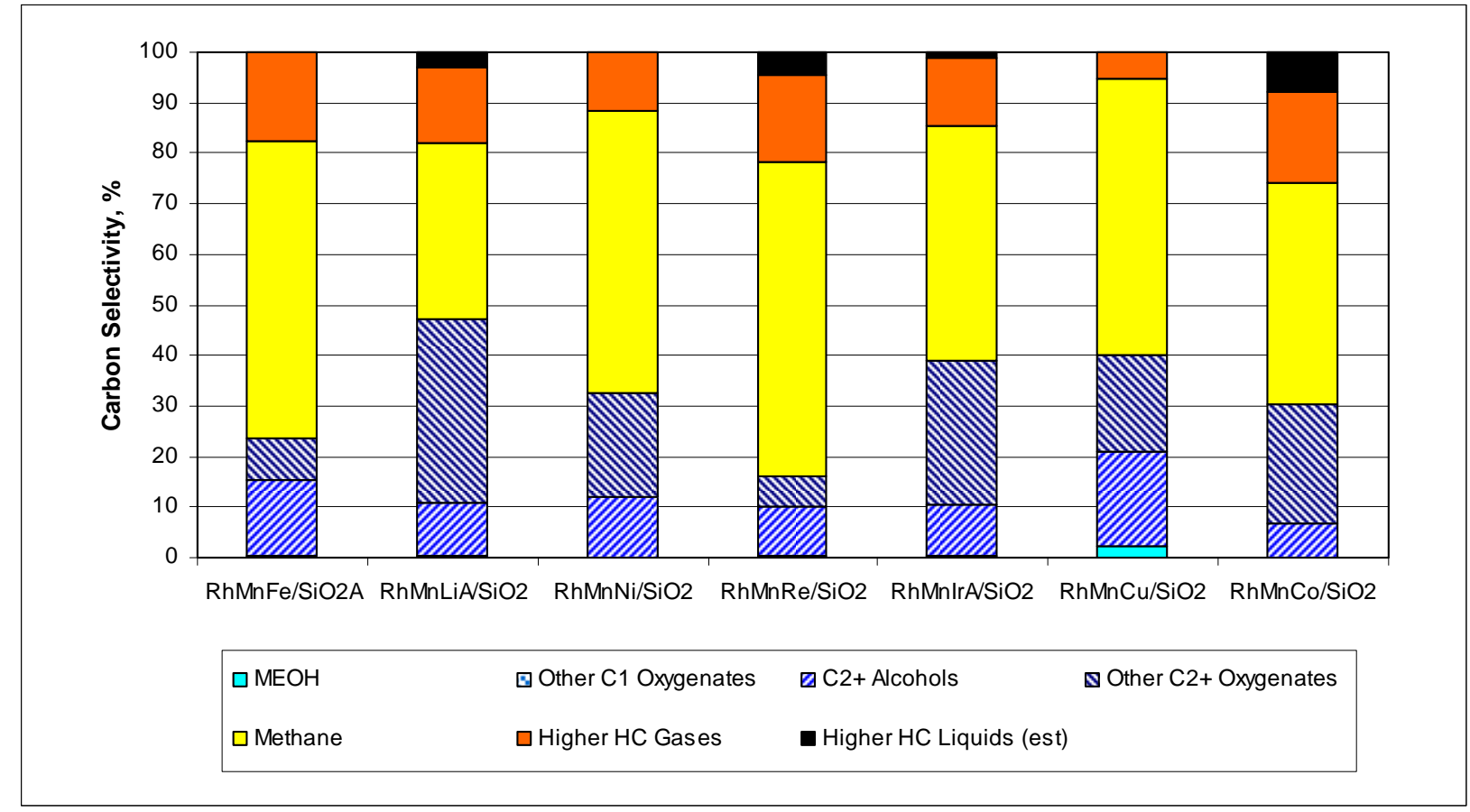

Figure 4.9. Comparison of Carbon Selectivities for $\mathrm{RhMn} / \mathrm{SiO}_{2}$ Catalysts with Different Promoters at Conditions Producing Maximum $\mathrm{C}_{2}^{+}$Oxygenate STYs

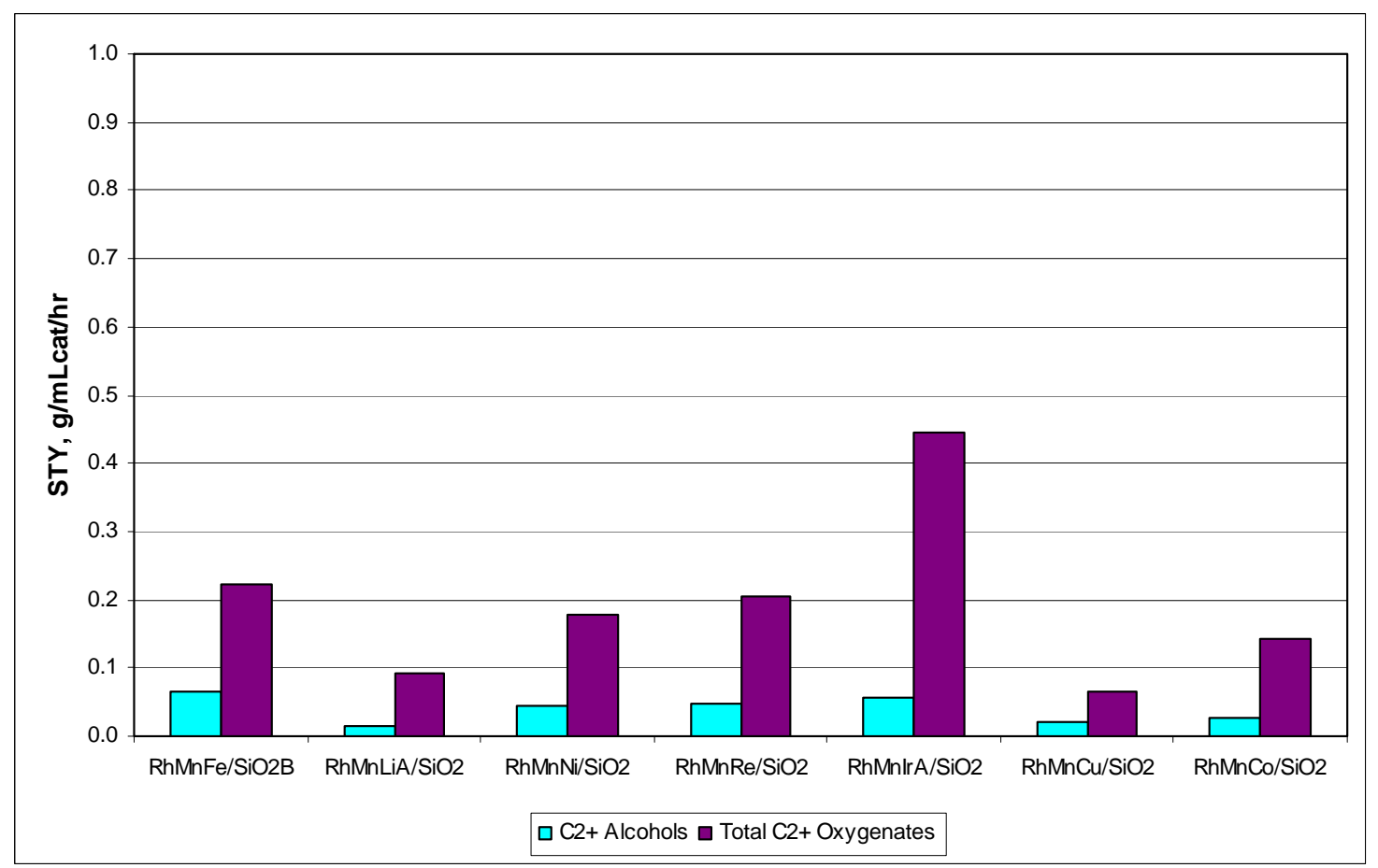

Figure 4.10. Comparison of $\mathrm{C}_{2}^{+}$Alcohols and Oxygenate STYs for $\mathrm{RhMn} / \mathrm{SiO}_{2}$ Catalysts with Different Promoters at Conditions Producing Maximum Carbon Selectivities to $\mathrm{C}_{2}^{+}$ Oxygenates 


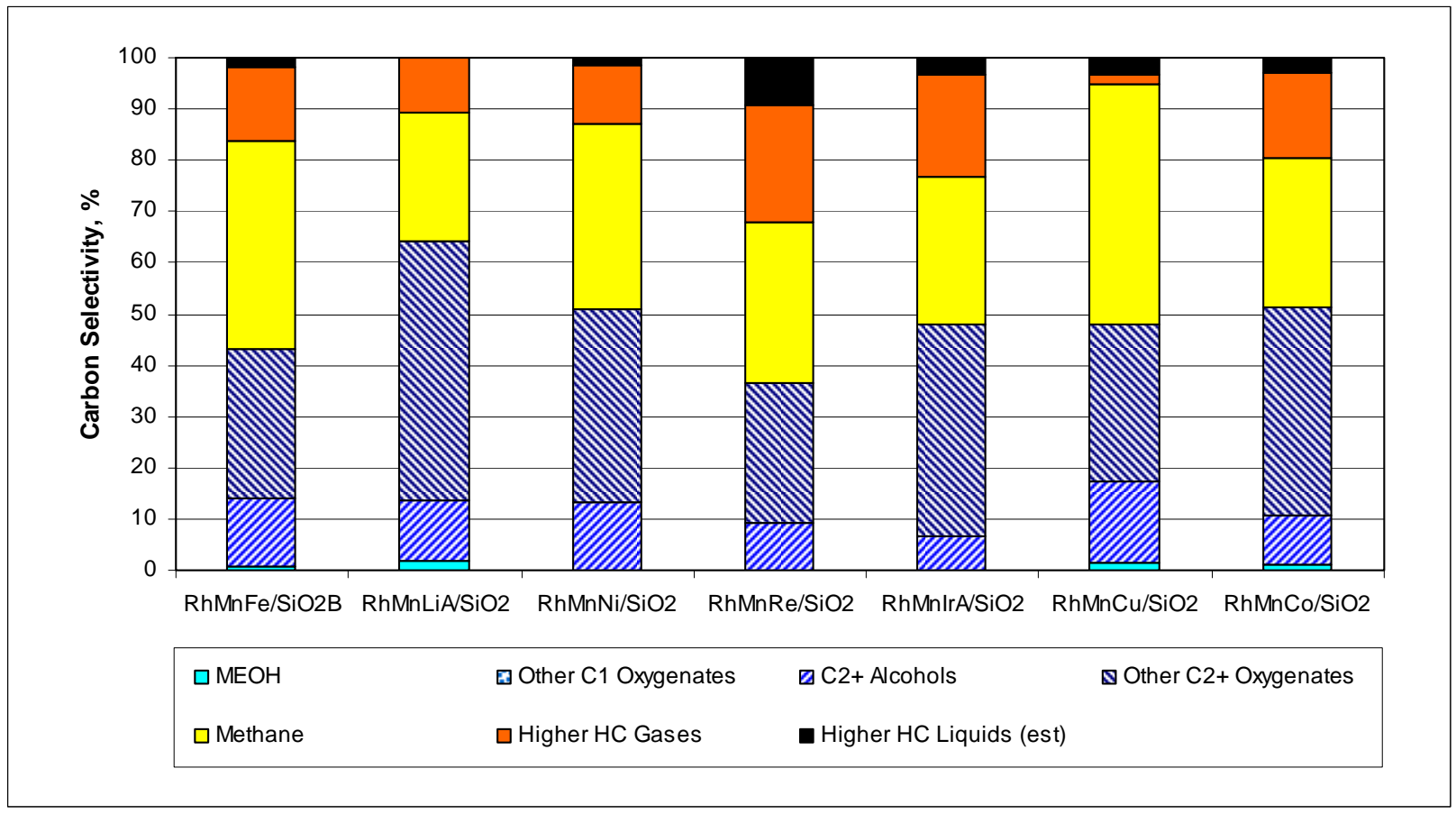

Figure 4.11. Comparison of Carbon Selectivities for $\mathrm{RhMn} / \mathrm{SiO}_{2}$ Catalysts with Different Promoters at Conditions Producing Maximum Carbon Selectivities to $\mathrm{C}_{2}{ }^{+}$Oxygenates

Figure 4.12 and Table 4.2 compare the promoters with regard to the selectivity of the catalysts toward $\mathrm{C}_{2}{ }^{+}$alcohols, the preferred product, relative to the other oxygenates that would be collected in the aqueous phase product, under conditions achieving maximum $\mathrm{C}_{2}{ }^{+}$oxygenates. It can be seen from Figure 4.12 that the $\mathrm{Fe}$ and $\mathrm{Re}$ promoters produced an aqueous product with the greatest carbon selectivity to $\mathrm{C}_{2}{ }^{+}$ alcohols (63 and 60\%, respectively), followed by $\mathrm{Cu}$ and $\mathrm{Ni}$ promoters (47 and 37\%, respectively). According to Table 4.2, the other oxygenates are mainly composed of acetaldehyde, acetic acid, and ethyl acetate with lesser amounts of methanol for these catalysts.

Carbon selectivity in the aqueous phase to the $\mathrm{C}_{2}{ }^{+}$alcohols decreased for all promoters at the lower catalyst temperatures where carbon selectivity to $\mathrm{C}_{2}{ }^{+}$oxygenates (consisting of acetaldehyde, acetic acid and ethyl acetate) was greatest, as shown in Figure 4.13 and Table 4.3. This implies that higher temperatures are required to hydrogenate of aldehydes and organic acids to alcohols. At the same time, however, higher temperatures also result in greater production of hydrocarbons resulting in an overall reduction in carbon selectivity to $\mathrm{C}_{2}^{+}$oxygenates. 


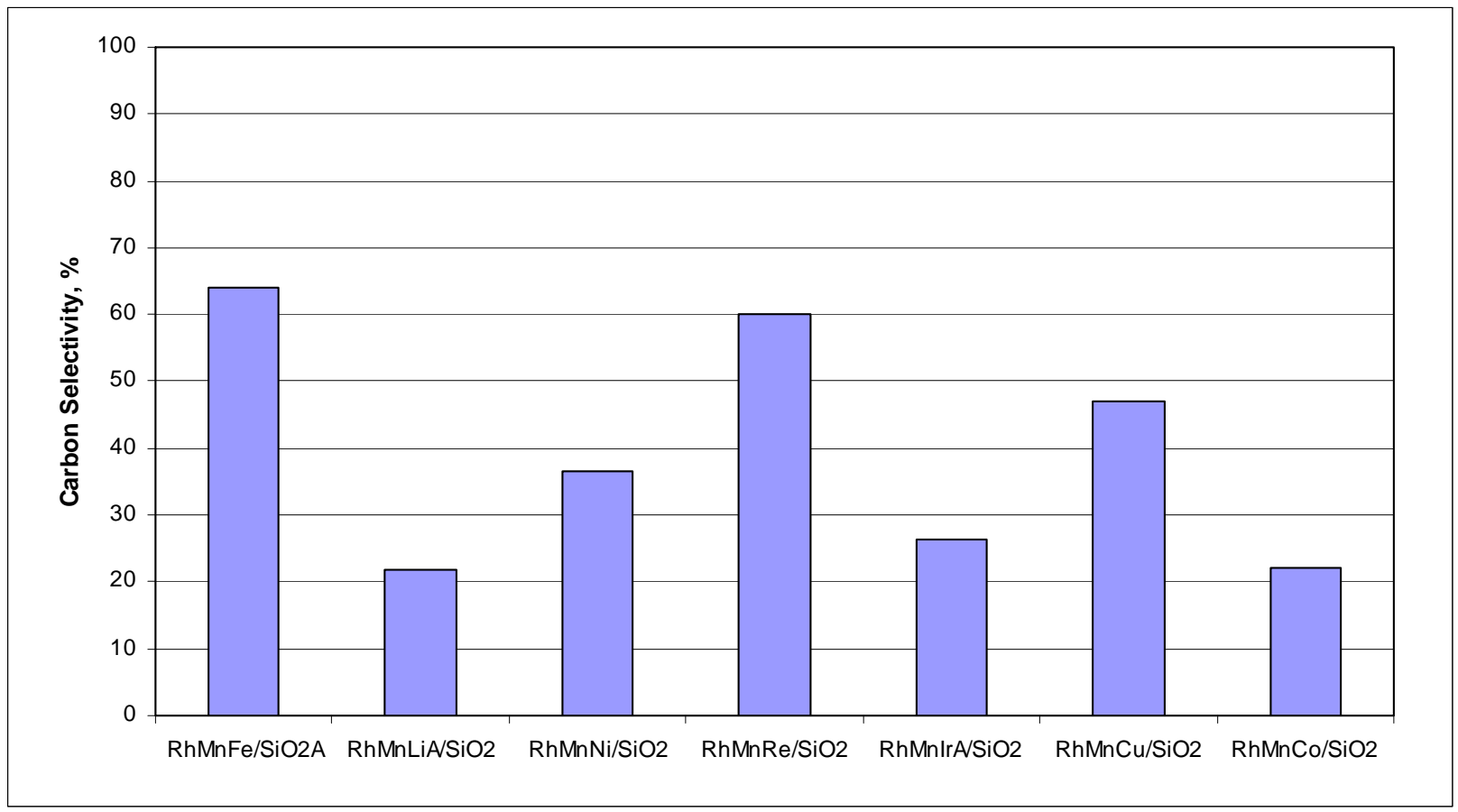

Figure 4.12. Carbon Selectivities to $\mathrm{C}_{2}{ }^{+}$Alcohols with Respect to all Oxygenates for $\mathrm{RhMn} / \mathrm{SiO}_{2}$ Catalysts with Different Promoters at Conditions Producing Maximum $\mathrm{C}_{2}{ }^{+}$Oxygenate STYs

Table 4.2. Carbon Selectivity Breakdown of Oxygenates for $\mathrm{RhMn} / \mathrm{SiO}_{2}$ Catalysts with Different Promoters at Conditions Producing Maximum $\mathrm{C}_{2}{ }^{+}$Oxygenate STYs

\begin{tabular}{|c|c|c|c|c|c|c|c|c|}
\hline \multirow[b]{2}{*}{ Catalyst } & \multicolumn{8}{|c|}{ Carbon Selectivity, \% } \\
\hline & Methanol & $\begin{array}{c}\text { Formic } \\
\text { Acid }\end{array}$ & Ethanol & $\begin{array}{c}\mathrm{C}_{2}+ \\
\text { Alcohols }\end{array}$ & $\begin{array}{c}\text { Acet- } \\
\text { aldehyde }\end{array}$ & $\begin{array}{c}\text { Ethyl } \\
\text { Acetate }\end{array}$ & $\begin{array}{c}\text { Acetic } \\
\text { Acid }\end{array}$ & $\begin{array}{l}\text { Propion- } \\
\text { aldehyde }\end{array}$ \\
\hline $\mathrm{RhMnFe} / \mathrm{SiO}_{2} \mathrm{~A}$ & 2.1 & 0.4 & 55.4 & 7.7 & 20.7 & 4.9 & 8.9 & 0.0 \\
\hline $\mathrm{RhMnNi} / \mathrm{SiO}_{2}$ & 0.0 & 0.0 & 33.0 & 3.5 & 35.4 & 13.8 & 14.2 & 0.0 \\
\hline $\mathrm{RhMnRe} / \mathrm{SiO}_{2}$ & 2.5 & 0.0 & 50.4 & 9.5 & 18.9 & 10.5 & 8.2 & 0.0 \\
\hline $\mathrm{RhMnIrASiO}_{2}$ & 0.6 & 0.0 & 23.4 & 3.0 & 37.7 & 18.7 & 12.6 & 3.9 \\
\hline $\mathrm{RhMnCu} / \mathrm{SiO}_{2}$ & 5.5 & 0.0 & 40.8 & 6.2 & 24.7 & 10.9 & 11.9 & 0.0 \\
\hline $\mathrm{RhMnCo} / \mathrm{SiO}_{2}$ & 0.0 & 0.0 & 17.1 & 5.1 & 38.5 & 19.0 & 14.1 & 6.2 \\
\hline
\end{tabular}




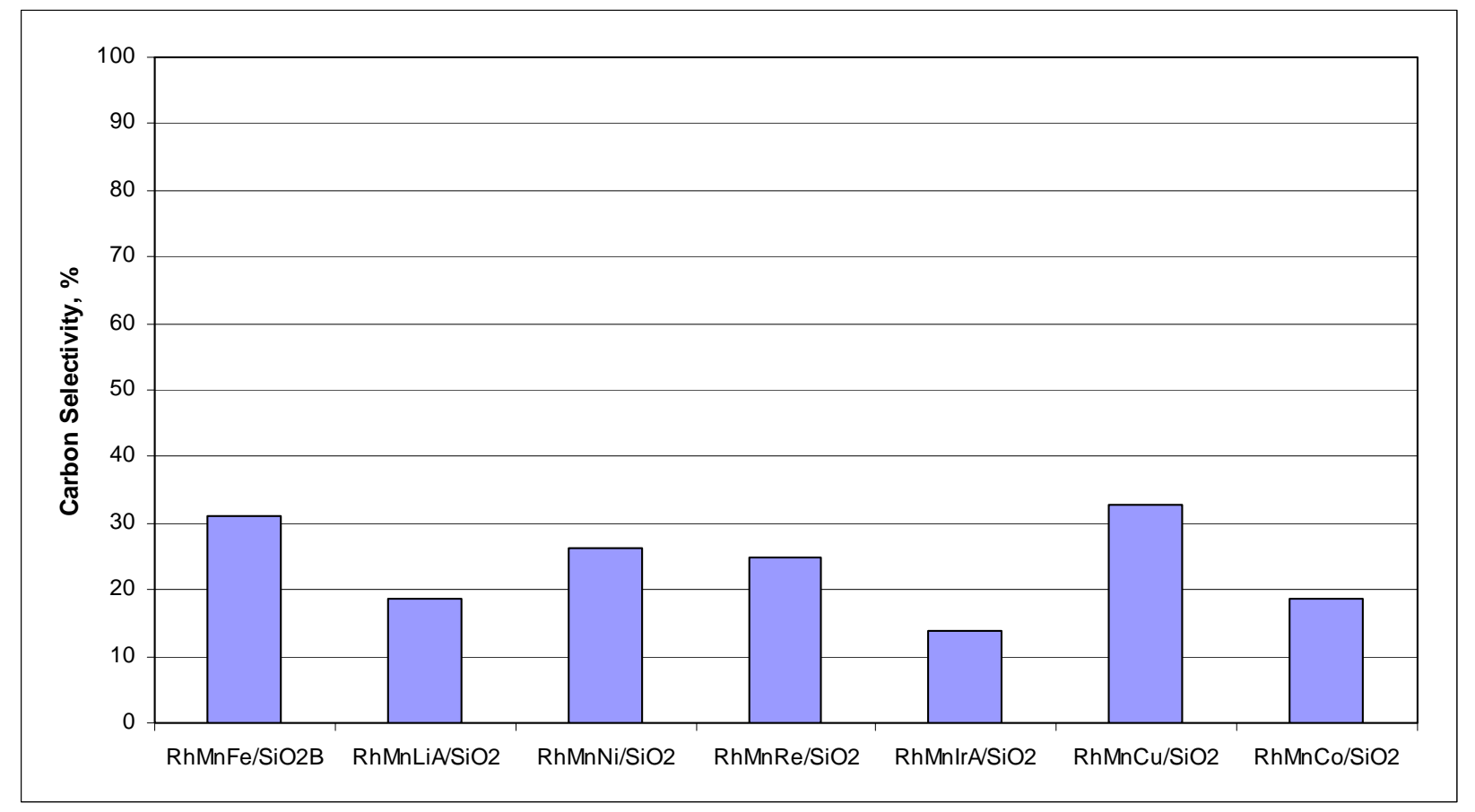

Figure 4.13. Carbon Selectivities to $\mathrm{C}_{2}{ }^{+}$Alcohols with Respect to All Oxygenates for $\mathrm{RhMn} / \mathrm{SiO}$ Catalysts with Different Promoters at Conditions Producing Maximum Carbon Selectivities to $\mathrm{C}_{2}^{+}$Oxygenates

Table 4.3. Carbon Selectivity Breakdown of Oxygenates for $\mathrm{RhMn} / \mathrm{SiO}_{2}$ Catalysts with Different Promoters at Conditions Producing Maximum Carbon Selectivities to $\mathrm{C}_{2}{ }^{+}$Oxygenates

\begin{tabular}{|c|c|c|c|c|c|c|c|c|}
\hline \multirow[b]{2}{*}{ Catalyst } & \multicolumn{8}{|c|}{ Carbon Selectivity, \% } \\
\hline & Methanol & $\begin{array}{c}\text { Formic } \\
\text { Acid }\end{array}$ & Ethanol & $\begin{array}{c}\mathrm{C}_{2}+ \\
\text { Alcohols }\end{array}$ & $\begin{array}{c}\text { Acet- } \\
\text { aldehyde }\end{array}$ & $\begin{array}{c}\text { Ethyl } \\
\text { Acetate }\end{array}$ & $\begin{array}{c}\text { Acetic } \\
\text { Acid }\end{array}$ & $\begin{array}{l}\text { Propion- } \\
\text { aldehyde }\end{array}$ \\
\hline $\mathrm{RhMnFe} / \mathrm{SiO}_{2} \mathrm{~B}$ & 0.8 & 0.4 & 31.7 & 6.1 & 24.2 & 18.6 & 18.6 & 0.0 \\
\hline $\mathrm{RhMnLiA} / \mathrm{SiO}_{2}$ & 2.8 & 0.0 & 14.1 & 4.4 & 23.5 & 14.4 & 40.7 & 0.0 \\
\hline $\mathrm{RhMnNi} / \mathrm{SiO}_{2}$ & 0.0 & 0.0 & 14.2 & 3.2 & 29.9 & 24.4 & 28.3 & 0.0 \\
\hline $\mathrm{RhMnRe} / \mathrm{SiO}_{2}$ & 0.0 & 0.0 & 18.2 & 6.7 & 31.8 & 22.4 & 20.9 & 0.0 \\
\hline $\mathrm{RhMnIrASiO}_{2}$ & 0.0 & 0.0 & 10.9 & 2.8 & 34.5 & 23.0 & 24.9 & 3.9 \\
\hline $\mathrm{RhMnCu} / \mathrm{SiO}_{2}$ & 3.3 & 0.0 & 28.5 & 4.2 & 27.9 & 14.5 & 21.7 & 0.0 \\
\hline $\mathrm{RhMnCo} / \mathrm{SiO}_{2}$ & 1.8 & 0.0 & 15.4 & 3.3 & 34.1 & 17.2 & 23.1 & 5.0 \\
\hline
\end{tabular}




\subsection{Conclusions and Recommendations}

Based on the promoters tested to date, the following general conclusions can be made:

- The highest $\mathrm{C}_{2}^{+}$oxygenate STYs occur between $300^{\circ}$ and $325^{\circ} \mathrm{C}$, where carbon conversion ranges between $\sim 25$ and 40\% (except for the $\mathrm{RhMnCu}$ catalyst, which had $\sim 9 \%$ carbon conversion).

- Carbon selectivities to $\mathrm{C}_{2}{ }^{+}$oxygenates decrease with increasing reaction temperatures because of higher carbon conversion to hydrocarbons.

- Carbon selectivities of the organics in the aqueous phase to $\mathrm{C}_{2}{ }^{+}$alcohols increase with higher reaction temperatures compared to the other oxygenates present there.

- The highest carbon selectivity to $\mathrm{C}_{2}{ }^{+}$oxygenates occurs at lower reaction temperatures and accompanying lower STYs.

In addition to these general trends, the test results singled out specific promoters that showed potential for improving the rhodium-based catalysts. The Ir promoter stood out in terms of significantly improving the STY of oxygenates with a maximum observed STY of $\sim 880 \mathrm{~g} / \mathrm{Lcat} / \mathrm{hr}$ followed by Li and $\mathrm{Ni}$ with observed maximum STYs of $480 \mathrm{~g} / \mathrm{Lcat} / \mathrm{hr}$. Selectivities to $\mathrm{C}_{2}{ }^{+}$oxygenates at the maximum $\mathrm{C}_{2}{ }^{+}$oxygenate STYs were 39, 47, and 32\%, respectively, under these conditions. Re and Cu promoters were relatively unremarkable in terms of STYs.

The Fe and Re promoters both stood out as achieving higher carbon selectivities to $\mathrm{C}_{2}{ }^{+}$alcohols with respect to all oxygenates in the aqueous product, followed by $\mathrm{Cu}$, with carbon selectivity ratios of 0.64 , 0.60 , and 0.47 , respectively, at conditions in which each achieved its highest $\mathrm{C}_{2}{ }^{+}$oxygenate STY. On the other hand, Ir and Li had low carbon selectivity ratios of 0.27 and 0.22 , respectively.

Although testing of candidate promoters is not complete, it appears that Ir and Li promoters will warrant further optimization and possibly combination in order to further improve STYs and carbon selectivities to $\mathrm{C}_{2}^{+}$oxygenates. However, using these promoters, it will be necessary to incorporate a separate hydrogenation catalyst to improve the yield of $\mathrm{C}_{2}^{+}$alcohols with respect to the other oxygenates. $\mathrm{Fe}, \mathrm{Re}$, and $\mathrm{Cu}$ stand out as possible candidates in this respect, but additional research is needed to examine whether they can be combined with the other promoters on the $\mathrm{Rh} / \mathrm{Mn} / \mathrm{SiO}_{2}$ catalyst or need to be optimized on a separate catalyst support that is either physically mixed or used in series with the promoted $\mathrm{Rh} / \mathrm{Mn} / \mathrm{SiO}_{2}$-based catalyst. 


\subsection{References}

Gerber MA, JF White, and DJ Stevens. Mixed Alcohol Synthesis Catalyst Screening. 2007. PNNL16763, Pacific Northwest National Laboratory, Richland Washington.

Phillips S, A Aden, J Jechura, D Dayton, and T Eggeman. 2007. Thermochemical Ethanol via Indirect Gasification and Mixed Alcohol Synthesis of Lignocellulosic Biomass. NREL-TP-510-41168, National Renewable Energy Laboratory, Golden, Colorado.

Quarderer GJ. April 1986. "Mixed alcohols from synthesis gas.” Proceedings from the $78^{\text {th }}$ Spring National AIChE Meeting, New Orleans.

Quarderer GJ and GA Cochran. 1986. Process for producing alcohols from synthesis gas. U.S. Patent No. 4,749,724.

Stiles AB, F Chen, JB Harrison, X Hu, DA Storm, and HX Yang. 1991. "Catalytic conversion of synthesis gas to methanol and other oxygenated products." Industrial and Engineering Chemistry Research, 30:811-821.

Tsotsis TT, VUS Rao, and LM Polinski. 1982. "Reaction rate oscillations during Fischer-Tropsch synthesis on Fe-precipitated Nu-1 zeolite-type catalysts.” AIChE Journal, 28(5):847-851. 


\section{Appendix}

Catalyst Testing Data 


\section{Appendix - Catalyst Testing Data}

Table A.1. Summary of Test Conditions and Catalyst Performance

\begin{tabular}{|c|c|c|c|c|c|c|c|c|c|c|c|c|c|c|c|c|c|c|c|c|}
\hline \multirow[b]{2}{*}{ Catalyst } & \multirow[b]{2}{*}{$\mathrm{H}_{2}: \mathrm{CO}$} & \multirow[b]{2}{*}{$\begin{array}{l}\text { Space Vel. } \\
\left(\mathbf{L} / \mathbf{L}_{\text {cat }} / \mathbf{h r}\right)\end{array}$} & \multirow[b]{2}{*}{$\begin{array}{c}\text { Temp. } \\
{ }^{\circ} \mathrm{C}\end{array}$} & \multirow[b]{2}{*}{$\begin{array}{c}\text { Carbon } \\
\text { Conc. } \\
\%\end{array}$} & \multirow[b]{2}{*}{\begin{tabular}{|c|} 
CO \\
Conc. \\
$\%$
\end{tabular}} & \multirow[b]{2}{*}{$\begin{array}{c}\text { CO } \\
\text { Conc. } \\
\%\end{array}$} & \multicolumn{7}{|c|}{ Carbon Selectivity (C-Mol\%) } & \multicolumn{6}{|c|}{ STY (g/mLcat/hr) } & \multirow[b]{2}{*}{$\begin{array}{c}\text { Carbon } \\
\text { Balance } \\
\left(\mathrm{C}_{\text {out }} / \mathrm{C}_{\text {in }}\right. \\
\%\end{array}$} \\
\hline & & & & & & & МeOH & $\begin{array}{c}\text { Other } \\
\text { C }_{1} \\
\text { Oxy. }\end{array}$ & $\begin{array}{l}\mathrm{C}_{2}+ \\
\text { Alc. }\end{array}$ & $\begin{array}{c}\text { Other } \\
\text { C }_{2}+ \\
\text { Oxy. }\end{array}$ & $\mathrm{CH}_{4}$ & $\begin{array}{c}\text { Higher } \\
\text { HC } \\
\text { Gases }\end{array}$ & $\begin{array}{c}\text { Higher } \\
\text { HC } \\
\text { Liquids } \\
\text { (est) }\end{array}$ & $\begin{array}{c}\mathrm{C}_{2}{ }^{+} \\
\text {Alcohols }\end{array}$ & $\begin{array}{c}\text { Other } \\
\mathrm{C}_{2}+ \\
\text { Oxy. }\end{array}$ & $\begin{array}{c}\text { Total } \\
\mathrm{C}_{2}{ }^{+} \\
\text {Oxy. }\end{array}$ & $\begin{array}{l}\text { HC } \\
\text { Liq. }\end{array}$ & МeOH & $\begin{array}{l}\text { Total } \\
\text { Liq. }\end{array}$ & \\
\hline $\mathrm{Rh} / \mathrm{Mn} / \mathrm{SiO}_{2} \mathrm{~A}$ & 2.1 & 3300 & 255 & 21.00 & 23.24 & 0.05 & 0.36 & 0.00 & 11.70 & 33.18 & 30.46 & 13.78 & 10.53 & 0.027 & 0.086 & 0.113 & 0.016 & 0.001 & 0.130 & 99 \\
\hline $\mathrm{Rh} / \mathrm{Mn} / \mathrm{SiO}_{2} \mathrm{~A}$ & 1.8 & 3300 & 280 & 37.13 & 42.03 & 1.12 & 0.29 & 0.00 & 9.75 & 22.56 & 33.37 & 10.92 & 23.11 & 0.043 & 0.111 & 0.155 & 0.066 & 0.002 & 0.222 & 103 \\
\hline $\mathrm{Rh} / \mathrm{Mn} / \mathrm{SiO}_{2} \mathrm{~A}$ & 2.0 & 3300 & 305 & 46.41 & 58.54 & 7.18 & 0.45 & 0.00 & 11.81 & 11.41 & 51.73 & 12.41 & 12.19 & 0.062 & 0.067 & 0.129 & 0.041 & 0.003 & 0.173 & 99 \\
\hline $\mathrm{Rh} / \mathrm{Mn} / \mathrm{Fe} / \mathrm{Al}_{2} \mathrm{O}_{3} \mathrm{~A}$ & 2.5 & 7400 & 257 & 21.75 & 26.21 & 0.41 & 0.24 & 0.08 & 14.24 & 24.79 & 37.17 & 23.48 & 0.00 & 0.071 & 0.138 & 0.209 & 0.000 & 0.002 & 0.210 & 98 \\
\hline $\mathrm{Rh} / \mathrm{Mn} / \mathrm{Fe} / \mathrm{Al}_{2} \mathrm{O}_{3} \mathrm{~A}$ & 2.6 & 15000 & 257 & 9.43 & 11.23 & $\begin{array}{c}-0.01 \\
\end{array}$ & 0.43 & 0.08 & 12.19 & 24.19 & 36.74 & 26.36 & 0.00 & 0.053 & 0.118 & 0.171 & 0.000 & 0.003 & 0.174 & 99 \\
\hline $\mathrm{Rh} / \mathrm{Mn} / \mathrm{Fe} / \mathrm{Al}_{2} \mathrm{O}_{3} \mathrm{~A}$ & 2.5 & 7400 & 285 & 36.34 & 43.12 & -0.35 & 0.17 & 0.08 & 13.55 & 19.92 & 47.56 & 18.72 & 0.00 & 0.114 & 0.184 & 0.298 & 0.000 & 0.002 & 0.300 & 91 \\
\hline $\mathrm{Rh} / \mathrm{Mn} / \mathrm{Fe} / \mathrm{Al}_{2} \mathrm{O}_{3} \mathrm{~A}$ & 2.6 & 11000 & 323 & 46.92 & 56.34 & 0.01 & 0.31 & 0.13 & 16.58 & 7.36 & 58.87 & 16.76 & 0.00 & 0.270 & 0.131 & 0.401 & 0.000 & 0.007 & 0.408 & 92 \\
\hline $\mathrm{Rh} / \mathrm{Mn} / \mathrm{Fe} / \mathrm{Al}_{2} \mathrm{O}_{3} \mathrm{~A}$ & 2.6 & 11000 & 326 & 45.37 & 55.54 & 0.40 & 0.38 & 0.00 & 15.56 & 5.52 & 63.62 & 14.91 & 0.00 & 0.246 & 0.094 & 0.339 & 0.000 & 0.009 & 0.348 & 95 \\
\hline $\mathrm{Rh} / \mathrm{Mn} / \mathrm{Fe} / \mathrm{Al}_{2} \mathrm{O}_{3} \mathrm{~A}$ & 2.0 & 11000 & 326 & 38.96 & 45.51 & 1.92 & 0.33 & 0.00 & 15.04 & 8.08 & 59.06 & 17.49 & 0.00 & 0.225 & 0.129 & 0.354 & 0.000 & 0.007 & 0.361 & 97 \\
\hline $\mathrm{Rh} / \mathrm{Mn} / \mathrm{Fe} / \mathrm{Al}_{2} \mathrm{O}_{3} \mathrm{~A}$ & 2.0 & 15000 & 326 & 32.00 & 37.21 & 1.57 & 0.47 & 0.08 & 14.22 & 7.76 & 61.79 & 15.69 & 0.00 & 0.233 & 0.136 & 0.369 & 0.000 & 0.011 & 0.380 & 97 \\
\hline $\mathrm{Rh} / \mathrm{Mn} / \mathrm{Fe} / \mathrm{Al}_{2} \mathrm{O}_{3} \mathrm{~A}$ & 2.4 & 15000 & 354 & 26.82 & 32.87 & 1.73 & 1.00 & 0.00 & 8.76 & 2.91 & 82.90 & 4.43 & 0.00 & 0.111 & 0.039 & 0.150 & 0.000 & 0.018 & 0.168 & 98 \\
\hline $\mathrm{Rh} / \mathrm{Mn} / \mathrm{Fe} / \mathrm{Al}_{2} \mathrm{O}_{3} \mathrm{~A}$ & 2.4 & 15000 & 402 & 65.05 & 90.11 & 14.85 & 0.04 & 0.00 & 0.32 & 0.10 & 97.78 & 1.75 & 0.00 & 0.010 & 0.003 & 0.013 & 0.000 & 0.002 & 0.015 & 93 \\
\hline $\mathrm{Rh} / \mathrm{Mn} / \mathrm{Fe} / \mathrm{Al}_{2} \mathrm{O}_{3} \mathrm{~B}$ & 2.4 & 7500 & 255 & 17.09 & 18.02 & \begin{tabular}{|c|}
-1.71 \\
\end{tabular} & 0.54 & 0.00 & 14.29 & 24.09 & 33.28 & 18.62 & 9.18 & 0.057 & 0.109 & 0.167 & 0.024 & 0.003 & 0.194 & 94 \\
\hline $\mathrm{Rh} / \mathrm{Mn} / \mathrm{Fe} / \mathrm{Al}_{2} \mathrm{O}_{3} \mathrm{~B}$ & 2.4 & 7500 & 275 & 29.69 & 32.06 & -2.40 & 0.24 & 0.00 & 11.56 & 18.82 & 36.56 & 16.89 & 15.93 & 0.081 & 0.144 & 0.225 & 0.072 & 0.002 & 0.299 & 90 \\
\hline $\mathrm{Rh} / \mathrm{Mn} / \mathrm{Fe} / \mathrm{Al}_{2} \mathrm{O}_{3} \mathrm{~B}$ & 2.3 & 11000 & 327 & 42.38 & 50.47 & 1.51 & 0.54 & 0.00 & 14.67 & 5.51 & 63.10 & 14.19 & 1.98 & 0.224 & 0.093 & 0.317 & 0.019 & 0.012 & 0.348 & 96 \\
\hline $\mathrm{Rh} / \mathrm{Mn} / \mathrm{Fe} / \mathrm{Al}_{2} \mathrm{O}_{3} \mathrm{~B}$ & 1.9 & 11000 & 325 & 35.29 & 41.82 & 1.55 & 0.53 & 0.00 & 13.66 & 10.97 & 57.16 & 16.06 & 1.61 & 0.195 & 0.168 & 0.363 & 0.015 & 0.011 & 0.388 & 98 \\
\hline $\mathrm{Rh} / \mathrm{Mn} / \mathrm{Fe} / \mathrm{Al}_{2} \mathrm{O}_{3} \mathrm{~B}$ & 1.8 & 11000 & 300 & 23.70 & 26.46 & -0.17 & 0.50 & 0.00 & 11.53 & 23.10 & 45.58 & 16.92 & 2.37 & 0.112 & 0.241 & 0.353 & 0.015 & 0.007 & 0.375 & 96 \\
\hline $\mathrm{Rh} / \mathrm{Mn} / \mathrm{Fe} / \mathrm{Al}_{2} \mathrm{O}_{3} \mathrm{~B}$ & 2.4 & 11000 & 300 & 27.49 & 32.05 & 0.10 & 0.60 & 0.00 & 13.19 & 19.88 & 49.94 & 13.92 & 2.46 & 0.128 & 0.204 & 0.333 & 0.015 & 0.008 & 0.356 & 98 \\
\hline $\mathrm{Rh} / \mathrm{Mn} / \mathrm{Fe} / \mathrm{Al}_{2} \mathrm{O}_{3} \mathrm{~B}$ & 2.4 & 7500 & 275 & 21.35 & 23.96 & -0.65 & 0.68 & 0.00 & 13.38 & 29.05 & 40.78 & 14.46 & 1.67 & 0.067 & 0.157 & 0.223 & 0.005 & 0.005 & 0.233 & 93 \\
\hline $\mathrm{Rh} / \mathrm{Mn} / \mathrm{Fe} / \mathrm{Al}_{2} \mathrm{O}_{3}$ & 2.2 & 7500 & 255 & 17.53 & 18.45 & -1.88 & 0.31 & 0.00 & 14.12 & 24.45 & 32.15 & 21.46 & 7.51 & 0.060 & 0.118 & 0.179 & 0.021 & 0.002 & 0.201 & 96 \\
\hline $\mathrm{Rh} / \mathrm{Mn} / \mathrm{Fe} / \mathrm{Al}_{2} \mathrm{O}_{3}$ & 2.3 & 7500 & 275 & 28.84 & 31.82 & -1.27 & 0.31 & 0.00 & 13.01 & 23.18 & 32.90 & 20.19 & 10.41 & 0.091 & 0.178 & 0.268 & 0.047 & 0.003 & 0.318 & 93 \\
\hline $\mathrm{Rh} / \mathrm{Mn} / \mathrm{Fe} / \mathrm{Al}_{2} \mathrm{O}_{3}$ & 1.9 & 11000 & 325 & 38.10 & 44.77 & 1.62 & 0.24 & 0.00 & 12.70 & 8.95 & 58.15 & 19.24 & 0.73 & 0.197 & 0.150 & 0.348 & 0.007 & 0.005 & 0.360 & 93 \\
\hline $\mathrm{Rh} / \mathrm{Mn} / \mathrm{Fe} / \mathrm{Al}_{2} \mathrm{O}_{3}$ & 1.9 & 11000 & 325 & 35.61 & 41.85 & 1.35 & 0.30 & 0.00 & 14.57 & 8.69 & 54.73 & 18.25 & 3.45 & 0.211 & 0.138 & 0.349 & 0.032 & 0.006 & 0.387 & 95 \\
\hline $\mathrm{Rh} / \mathrm{Mn} / \mathrm{Fe} / \mathrm{Al}_{2} \mathrm{O}_{3}$ & 1.9 & 9300 & 301 & 29.41 & 34.59 & 1.11 & 0.36 & 0.00 & 12.27 & 18.44 & 47.44 & 19.19 & 2.31 & 0.122 & 0.198 & 0.321 & 0.015 & 0.005 & 0.340 & 95 \\
\hline $\mathrm{Rh} / \mathrm{Mn} / \mathrm{Li} / \mathrm{Al}_{2} \mathrm{O}_{3}$ & 1.9 & 7500 & 256 & 4.69 & 4.08 & -1.24 & 0.93 & 0.00 & 13.16 & 44.36 & 25.19 & 13.17 & 3.18 & 0.016 & 0.065 & 0.081 & 0.003 & 0.002 & 0.085 & 95 \\
\hline $\mathrm{Rh} / \mathrm{Mn} / \mathrm{Li} / \mathrm{Al}_{2} \mathrm{O}_{3}$ & 1.9 & 7500 & 277 & 10.88 & 10.93 & -1.36 & 0.80 & 0.00 & 10.78 & 38.18 & 28.21 & 22.03 & 0.00 & 0.031 & 0.127 & 0.158 & 0.000 & 0.003 & 0.162 & 92 \\
\hline $\mathrm{Rh} / \mathrm{Mn} / \mathrm{Li} / \mathrm{Al}_{2} \mathrm{O}_{3}$ & 1.9 & 11000 & 302 & 17.98 & 19.44 & -0.88 & 0.66 & 0.00 & 11.38 & 39.35 & 29.36 & 18.48 & 0.78 & 0.081 & 0.312 & 0.393 & 0.004 & 0.007 & 0.404 & 94 \\
\hline $\mathrm{Rh} / \mathrm{Mn} / \mathrm{Li} / \mathrm{Al}_{2} \mathrm{O}_{3}$ & 1.9 & 11000 & 302 & 18.92 & 21.06 & -0.33 & 0.66 & 0.00 & 11.41 & 38.38 & 26.70 & 16.61 & 6.24 & 0.086 & 0.325 & 0.411 & 0.031 & 0.007 & 0.449 & 98 \\
\hline $\mathrm{Rh} / \mathrm{Mn} / \mathrm{Li} / \mathrm{Al}_{2} \mathrm{O}_{3}$ & 1.9 & 11000 & 293 & 2.40 & 2.30 & -0.42 & 2.61 & 0.00 & 17.30 & 33.68 & 47.00 & 0.00 & 0.00 & 0.017 & 0.038 & 0.055 & 0.000 & 0.004 & 0.058 & 98 \\
\hline $\mathrm{Rh} / \mathrm{Mn} / \mathrm{Li} / \mathrm{Al}_{2} \mathrm{O}_{3}$ & 1.9 & 11000 & 326 & 8.13 & 9.97 & 0.74 & 2.12 & 0.00 & 17.14 & 17.24 & 52.10 & 11.77 & 0.00 & 0.056 & 0.066 & 0.122 & 0.000 & 0.010 & 0.131 & 95 \\
\hline $\mathrm{Rh} / \mathrm{Mn} / \mathrm{Li} / \mathrm{Al}_{2} \mathrm{O}_{3}$ & 1.9 & 11000 & 350 & 23.88 & 30.27 & 2.93 & 1.79 & 0.00 & 20.33 & 15.91 & 47.91 & 14.39 & 0.00 & 0.195 & 0.178 & 0.373 & 0.000 & 0.025 & 0.398 & 99 \\
\hline $\mathrm{Rh} / \mathrm{Mn} / \mathrm{LiA} / \mathrm{Al}_{2} \mathrm{O}_{3}$ & 1.8 & 7500 & 257 & 4.74 & 5.34 & 0.03 & 1.82 & 0.00 & 11.87 & 50.36 & 25.26 & 10.69 & 0.00 & 0.015 & 0.078 & 0.093 & 0.000 & 0.003 & 0.097 & 97 \\
\hline $\mathrm{Rh} / \mathrm{Mn} / \mathrm{LiA} / \mathrm{Al}_{2} \mathrm{O}_{3}$ & 1.9 & 7500 & 277 & 11.14 & 12.47 & -0.05 & 0.65 & 0.00 & 9.68 & 40.98 & 27.92 & 20.77 & 0.00 & 0.029 & 0.139 & 0.168 & 0.000 & 0.003 & 0.171 & 94 \\
\hline $\mathrm{Rh} / \mathrm{Mn} / \mathrm{LiA} / \mathrm{Al}_{2} \mathrm{O}_{3}$ & 1.9 & 11000 & 300 & 19.56 & 21.84 & -0.15 & 0.65 & 0.00 & 12.01 & 41.33 & 29.36 & 14.96 & 1.68 & 0.092 & 0.357 & 0.449 & 0.008 & 0.007 & 0.464 & 98 \\
\hline $\mathrm{Rh} / \mathrm{Mn} / \mathrm{LiA} / \mathrm{Al}_{2} \mathrm{O}_{3}$ & 1.9 & 11000 & 305 & 24.49 & 28.21 & 0.67 & 0.42 & 0.00 & 10.32 & 36.55 & 34.90 & 14.66 & 3.14 & 0.099 & 0.386 & 0.485 & 0.019 & 0.006 & 0.510 & 97 \\
\hline
\end{tabular}


Table A.1. Summary of Test Conditions and Catalyst Performance

\begin{tabular}{|c|c|c|c|c|c|c|c|c|c|c|c|c|c|c|c|c|c|c|c|c|}
\hline \multirow[b]{2}{*}{ Catalyst } & \multirow[b]{2}{*}{$\mathrm{H}_{2}: \mathrm{CO}$} & \multirow[b]{2}{*}{$\mid \begin{array}{l}\text { Space Vel. } \\
\left(\mathrm{L} / \mathbf{L}_{\text {cat }} / \mathbf{h r}\right)\end{array}$} & \multirow[b]{2}{*}{$\begin{array}{c}\text { Temp. } \\
{ }^{\circ} \mathrm{C}\end{array}$} & \multirow[b]{2}{*}{$\begin{array}{c}\text { Carbon } \\
\text { Conc. } \\
\%\end{array}$} & \multirow[b]{2}{*}{$\begin{array}{c}\text { CO } \\
\text { Conc. } \\
\%\end{array}$} & \multirow[b]{2}{*}{$\begin{array}{c}\text { CO } \\
\text { Conc. } \\
\%\end{array}$} & \multicolumn{7}{|c|}{ Carbon Selectivity (C-Mol\%) } & \multicolumn{6}{|c|}{ STY (g/mLcat/hr) } & \multirow[b]{2}{*}{$\begin{array}{c}\text { Carbon } \\
\text { Balance } \\
\left(\mathrm{C}_{\text {out }} / \mathrm{C}_{\text {in }}\right) \\
\%\end{array}$} \\
\hline & & & & & & & $\mathrm{MeOH}$ & $\begin{array}{c}\text { Other } \\
\text { C }_{1} \\
\text { Oxy. }\end{array}$ & $\begin{array}{l}\mathrm{C}_{2}{ }^{+} \\
\text {Alc. }\end{array}$ & $\begin{array}{c}\text { Other } \\
\mathrm{C}_{2}+ \\
\text { Oxy. }\end{array}$ & $\mathrm{CH}_{4}$ & $\begin{array}{c}\text { Higher } \\
\text { HC } \\
\text { Gases }\end{array}$ & $\begin{array}{c}\text { Higher } \\
\text { HC } \\
\text { Liquids } \\
\text { (est) }\end{array}$ & $\begin{array}{c}\mathrm{C}_{2}+ \\
\text { Alcohols }\end{array}$ & $\begin{array}{c}\text { Other } \\
\mathrm{C}_{2}+ \\
\text { Oxy. }\end{array}$ & $\begin{array}{c}\text { Total } \\
\mathrm{C}_{2}+ \\
\text { Oxy. }\end{array}$ & $\begin{array}{l}\text { HC } \\
\text { Liq. }\end{array}$ & MeOH & $\begin{array}{l}\text { Total } \\
\text { Liq. }\end{array}$ & \\
\hline $\mathrm{Rh} / \mathrm{Mn} / \mathrm{Ni} / \mathrm{Al}_{2} \mathrm{O}_{3}$ & 1.8 & 7500 & 256 & 7.74 & 8.17 & -0.58 & 0.00 & 0.00 & 9.71 & 46.05 & 33.41 & 10.83 & 0.00 & 0.021 & 0.112 & 0.133 & 0.000 & 0.000 & 0.133 & 96 \\
\hline $\mathrm{Rh} / \mathrm{Mn} / \mathrm{Ni} / \mathrm{Al}_{2} \mathrm{O}_{3}$ & 1.8 & 7500 & 277 & 16.67 & 18.44 & -0.27 & 0.00 & 0.00 & 7.94 & 37.72 & 36.85 & 16.32 & 1.16 & 0.036 & 0.192 & 0.228 & 0.003 & 0.000 & 0.232 & 93 \\
\hline $\mathrm{Rh} / \mathrm{Mn} / \mathrm{Ni} / \mathrm{Al}_{2} \mathrm{O}_{3}$ & 1.8 & 11000 & 300 & 18.00 & 19.66 & -0.52 & 0.00 & 0.00 & 8.59 & 24.17 & 51.32 & 15.62 & 0.29 & 0.065 & 0.202 & 0.267 & 0.001 & 0.000 & 0.269 & 91 \\
\hline $\mathrm{Rh} / \mathrm{Mn} / \mathrm{Ni} / \mathrm{Al}_{2} \mathrm{O}_{3}$ & 1.8 & 11000 & 305 & 18.25 & 19.96 & -0.48 & 0.00 & 0.00 & 11.11 & 28.57 & 46.16 & 13.56 & 0.60 & 0.086 & 0.236 & 0.322 & 0.003 & 0.000 & 0.325 & 94 \\
\hline $\mathrm{Rh} / \mathrm{Mn} / \mathrm{Ni} / \mathrm{Al}_{2} \mathrm{O}_{3}$ & 1.8 & 11000 & 325 & 34.06 & 39.05 & 1.00 & 0.00 & 0.00 & 11.86 & 20.60 & 56.10 & 11.26 & 0.18 & 0.169 & 0.307 & 0.476 & 0.002 & 0.000 & 0.478 & 100 \\
\hline $\mathrm{Rh} / \mathrm{Mn} / \mathrm{Ni} / \mathrm{Al}_{2} \mathrm{O}_{3}$ & 1.8 & 7500 & 312 & 36.91 & 42.42 & 1.08 & 0.00 & 0.00 & 11.33 & 26.08 & 49.15 & 12.32 & 1.12 & 0.116 & 0.281 & 0.397 & 0.007 & 0.000 & 0.404 & 96 \\
\hline $\mathrm{Rh} / \mathrm{Mn} / \mathrm{Ni} / \mathrm{Al}_{2} \mathrm{O}_{3}$ & 1.8 & 7500 & 277 & 11.99 & 12.90 & -0.61 & 0.00 & 0.01 & 13.40 & 37.34 & 36.45 & 11.50 & 1.30 & 0.044 & 0.135 & 0.179 & 0.003 & 0.000 & 0.182 & 97 \\
\hline $\mathrm{Rh} / \mathrm{Mn} / \mathrm{Ir} / \mathrm{Al}_{2} \mathrm{O}_{3}$ & 1.8 & 7500 & 256 & 21.47 & 24.07 & -0.05 & 0.00 & 0.00 & 5.47 & 52.18 & 22.12 & 20.20 & 0.27 & 0.031 & 0.342 & 0.373 & 0.001 & 0.000 & 0.374 & 96 \\
\hline $\mathrm{Rh} / \mathrm{Mn} / \mathrm{Ir} / \mathrm{Al}_{2} \mathrm{O}_{3}$ & 1.8 & 7500 & 267 & 29.07 & 31.92 & -0.70 & 0.00 & 0.00 & 6.42 & 36.77 & 29.58 & 21.40 & 5.83 & 0.049 & 0.323 & 0.372 & 0.030 & 0.000 & 0.402 & 90 \\
\hline $\mathrm{Rh} / \mathrm{Mn} / \mathrm{Ir} / \mathrm{Al}_{2} \mathrm{O}_{3}$ & 1.8 & 11000 & 328 & 50.78 & 58.25 & 1.32 & 0.14 & 0.00 & 8.53 & 14.40 & 55.01 & 20.37 & 1.54 & 0.176 & 0.322 & 0.498 & 0.020 & 0.004 & 0.523 & 94 \\
\hline $\mathrm{Rh} / \mathrm{Mn} / \mathrm{IrA} / \mathrm{Al}_{2} \mathrm{O}_{3}$ & 1.7 & 7500 & 256 & 17.70 & 21.73 & 1.93 & 0.00 & 0.00 & 6.57 & 46.72 & 26.03 & 20.69 & 0.00 & 0.032 & 0.257 & 0.290 & 0.000 & 0.000 & 0.290 & 110 \\
\hline $\mathrm{Rh} / \mathrm{Mn} / \mathrm{IrA} / \mathrm{Al}_{2} \mathrm{O}_{3}$ & 1.7 & 7500 & 276 & 30.87 & 34.66 & 0.14 & 0.00 & 0.00 & 6.57 & 41.22 & 28.83 & 20.18 & 3.20 & 0.056 & 0.388 & 0.444 & 0.018 & 0.000 & 0.462 & 94 \\
\hline $\mathrm{Rh} / \mathrm{Mn} / \mathrm{IrA} / \mathrm{Al}_{2} \mathrm{O}_{3}$ & 1.9 & 11000 & 303 & 36.63 & 40.26 & -1.10 & 0.00 & 0.00 & 7.26 & 34.58 & 37.80 & 19.13 & 1.22 & 0.106 & 0.541 & 0.648 & 0.012 & 0.000 & 0.659 & 95 \\
\hline $\mathrm{Rh} / \mathrm{Mn} / \mathrm{IrA} / \mathrm{Al}_{2} \mathrm{O}_{3}$ & 1.9 & 11000 & 316 & 43.18 & 48.80 & 0.54 & 0.00 & 0.00 & 9.26 & 29.01 & 40.49 & 18.05 & 3.20 & 0.160 & 0.527 & 0.687 & 0.035 & 0.000 & 0.722 & 97 \\
\hline $\mathrm{Rh} / \mathrm{Mn} / \mathrm{IrA} / \mathrm{Al}_{2} \mathrm{O}_{3}$ & 1.9 & 11000 & 323 & 43.58 & 49.72 & 0.97 & 0.00 & 0.00 & 9.69 & 23.16 & 47.39 & 17.44 & 2.32 & 0.170 & 0.425 & 0.595 & 0.026 & 0.000 & 0.621 & 95 \\
\hline $\mathrm{Rh} / \mathrm{Mn} / \mathrm{IrA} / \mathrm{Al}_{2} \mathrm{O}_{3}$ & 1.9 & 15000 & 325 & 37.79 & 42.72 & 0.42 & 0.25 & 0.00 & 10.25 & 28.32 & 46.66 & 13.52 & 0.99 & 0.210 & 0.596 & 0.805 & 0.013 & 0.007 & 0.825 & 99 \\
\hline $\mathrm{Rh} / \mathrm{Mn} / \mathrm{IrA} / \mathrm{Al}_{2} \mathrm{O}_{3}$ & 1.9 & 11000 & 303 & 28.92 & 32.34 & -0.11 & 0.00 & 0.00 & 8.39 & 33.66 & 39.08 & 18.87 & 0.00 & 0.097 & 0.413 & 0.511 & 0.000 & 0.000 & 0.511 & 95 \\
\hline $\mathrm{Rh} / \mathrm{Mn} / \mathrm{IrA} / \mathrm{Al}_{2} \mathrm{O}_{3}$ & 2.0 & 11000 & 304 & 27.14 & 30.23 & -0.44 & 0.00 & 0.00 & 8.70 & 34.14 & 40.96 & 16.20 & 0.00 & 0.093 & 0.387 & 0.480 & 0.000 & 0.000 & 0.480 & 96 \\
\hline $\mathrm{Rh} / \mathrm{Mn} / \mathrm{Re} / \mathrm{Al}_{2} \mathrm{O}_{3}$ & 1.7 & 7500 & 256 & 19.02 & 21.33 & -0.06 & 0.00 & 0.00 & 9.07 & 27.29 & 31.45 & 22.83 & 9.36 & 0.047 & 0.158 & 0.205 & 0.032 & 0.000 & 0.237 & 98 \\
\hline $\mathrm{Rh} / \mathrm{Mn} / \mathrm{Re} / \mathrm{Al}_{2} \mathrm{O}_{3}$ & 1.7 & 7500 & 273 & 28.97 & 32.34 & -0.23 & 0.00 & 0.00 & 8.35 & 19.34 & 35.55 & 23.77 & 12.98 & 0.067 & 0.168 & 0.236 & 0.068 & 0.000 & 0.303 & 95 \\
\hline $\mathrm{Rh} / \mathrm{Mn} / \mathrm{Re} / \mathrm{Al}_{2} \mathrm{O}_{3}$ & 1.8 & 7500 & 273 & 27.57 & 30.98 & 0.13 & 0.00 & 0.00 & 10.39 & 18.09 & 36.61 & 22.93 & 11.97 & 0.078 & 0.147 & 0.225 & 0.058 & 0.000 & 0.283 & 91 \\
\hline $\mathrm{Rh} / \mathrm{Mn} / \mathrm{Re} / \mathrm{Al}_{2} \mathrm{O}_{3}$ & 1.8 & 11000 & 323.54 & 37.98 & 44.82 & 1.63 & 0.40 & 0.00 & 9.72 & 6.09 & 62.07 & 17.08 & 4.63 & 0.154 & 0.102 & 0.257 & 0.047 & 0.009 & 0.313 & 95 \\
\hline $\mathrm{Rh} / \mathrm{Mn} / \mathrm{Cu} / \mathrm{Al}_{2} \mathrm{O}_{3}$ & 1.9 & 7500 & 256 & 1.10 & 1.54 & 0.32 & 0.00 & 0.00 & 0.00 & 0.00 & 95.96 & 4.04 & 0.00 & 0.000 & 0.000 & 0.000 & 0.000 & 0.000 & 0.000 & 97 \\
\hline $\mathrm{Rh} / \mathrm{Mn} / \mathrm{Cu} / \mathrm{Al}_{2} \mathrm{O}_{3}$ & 1.9 & 7500 & 276 & 4.95 & 5.90 & 0.40 & 1.60 & 0.00 & 15.63 & 30.66 & 46.99 & 1.94 & 3.17 & 0.021 & 0.045 & 0.065 & 0.003 & 0.003 & 0.071 & 99 \\
\hline $\mathrm{Rh} / \mathrm{Mn} / \mathrm{Cu} / \mathrm{Al}_{2} \mathrm{O}_{3}$ & 1.9 & 11000 & 300 & 6.41 & 6.91 & -0.26 & 1.59 & 0.00 & 14.31 & 21.28 & 59.03 & 3.79 & 0.00 & 0.037 & 0.059 & 0.095 & 0.000 & 0.006 & 0.101 & 97 \\
\hline $\mathrm{Rh} / \mathrm{Mn} / \mathrm{Cu} / \mathrm{Al}_{2} \mathrm{O}_{3}$ & 1.9 & 11000 & 315 & 9.46 & 10.37 & -0.23 & 2.19 & 0.00 & 18.76 & 18.97 & 54.82 & 5.26 & 0.00 & 0.071 & 0.076 & 0.147 & 0.000 & 0.012 & 0.159 & 98 \\
\hline $\mathrm{Rh} / \mathrm{Mn} / \mathrm{Cu} / \mathrm{Al}_{2} \mathrm{O}_{3}$ & 2.0 & 11000 & 324 & 9.47 & 10.43 & -0.19 & 2.06 & 0.00 & 15.11 & 11.35 & 63.71 & 7.78 & 0.00 & 0.057 & 0.046 & 0.102 & 0.000 & 0.011 & 0.113 & 97 \\
\hline $\mathrm{Rh} / \mathrm{Mn} / \mathrm{Cu} / \mathrm{Al}_{2} \mathrm{O}_{3}$ & 2.0 & 11000 & 337 & 12.14 & 13.26 & -0.36 & 2.25 & 0.00 & 13.14 & 8.08 & 68.56 & 7.97 & 0.00 & 0.063 & 0.042 & 0.105 & 0.000 & 0.015 & 0.121 & 95 \\
\hline $\mathrm{Rh} / \mathrm{Mn} / \mathrm{Co} / \mathrm{Al}_{2} \mathrm{O}_{3}$ & 1.9 & 7500 & 256 & 9.19 & 10.56 & 0.31 & 0.77 & 0.00 & 7.76 & 33.03 & 33.74 & 24.70 & 0.00 & 0.019 & 0.087 & 0.105 & 0.000 & 0.003 & 0.108 & 95 \\
\hline $\mathrm{Rh} / \mathrm{Mn} / \mathrm{Co} / \mathrm{Al}_{2} \mathrm{O}_{3}$ & 1.9 & 7500 & 256 & 9.93 & 10.05 & -1.18 & 0.95 & 0.00 & 9.60 & 40.85 & 29.20 & 16.56 & 2.84 & 0.025 & 0.117 & 0.143 & 0.005 & 0.004 & 0.151 & 97 \\
\hline $\mathrm{Rh} / \mathrm{Mn} / \mathrm{Co} / \mathrm{Al}_{2} \mathrm{O}_{3}$ & 2.0 & 11000 & 299 & 28.48 & 31.69 & -0.18 & 0.00 & 0.00 & 6.76 & 23.70 & 43.84 & 18.00 & 7.70 & 0.075 & 0.276 & 0.351 & 0.055 & 0.000 & 0.406 & 95 \\
\hline $\mathrm{Rh} / \mathrm{Mn} / \mathrm{Co} / \mathrm{Al}_{2} \mathrm{O}_{3}$ & 2.0 & 11000 & 323 & 37.57 & 42.94 & 0.94 & 0.48 & 0.00 & 9.68 & 11.30 & 60.62 & 14.73 & 3.20 & 0.143 & 0.176 & 0.318 & 0.030 & 0.010 & 0.358 & 95 \\
\hline $\mathrm{Rh} / \mathrm{Mn} / \mathrm{Co} / \mathrm{Al}_{2} \mathrm{O}_{3}$ & 1.9 & 11000 & 307 & 29.37 & 33.08 & 0.02 & 0.33 & 0.00 & 7.25 & 21.65 & 50.20 & 20.48 & 0.10 & 0.085 & 0.270 & 0.355 & 0.001 & 0.005 & 0.361 & 95 \\
\hline
\end{tabular}

